\title{
Land use effect and hydrological control on nitrate yield in subtropical mountainous watersheds
}

\author{
J.-C. Huang ${ }^{1}$, T.-Y. Lee ${ }^{1}$, S.-J. Kao ${ }^{2,3}$, S.-C. Hsu' ${ }^{2}$, H.-J. Lin ${ }^{4}$, and T.-R. Peng ${ }^{5}$ \\ ${ }^{1}$ Department of Geography, National Taiwan University, Taipei, Taiwan \\ ${ }^{2}$ Research Center for Environmental Changes, Academia Sinica, Taipei, Taiwan \\ ${ }^{3}$ State Key Laboratory of Marine Environmental Science, Xiamen University, Xiamen, China \\ ${ }^{4}$ Department of Life Sciences, National Chung Hsing University, Taichung, Taiwan \\ ${ }^{5}$ Department of Soil and Environmental Sciences, National Chung Hsing University, Taichung, Taiwan
}

Correspondence to: J.-C. Huang (riverhuang@ntu.edu.tw)

Received: 5 November 2010 - Published in Hydrol. Earth Syst. Sci. Discuss.: 7 December 2010

Revised: 5 January 2012 - Accepted: 25 January 2012 - Published: 6 March 2012

\begin{abstract}
Nitrate export in small subtropical watersheds is rarely observed and the estimation of individual land use nitrate yield from a mixed combination within catchments has scarcely been studied. In this study the nitrate concentrations at 16 nested catchments in the Chi-Chia-Wan watershed in Central Taiwan were measured during 2007-2008. A 3-layer TOPMODEL was applied to estimate daily discharge for ungauged sub-catchments. The observed nitrate concentrations and the simulated discharges were used for nitrate flux estimations through four flux methods. Meanwhile, a new deconvolution computation was developed to resolve the nitrate yield of each land use from within the mixed combinations.

The results showed that the observed mean $\mathrm{NO}_{3}-\mathrm{N}$ concentration in relatively pristine catchments was approximately $0.145 \pm 0.103 \mathrm{mgl}^{-1}$, which is comparable with other forestry catchments around the world. However, the higher rainfall/runoff, substantial $\mathrm{N}$ deposition, and other nitrogen sources resulted in significantly higher annual ex-

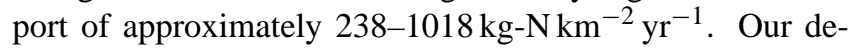
convolution computation showed that the background yield

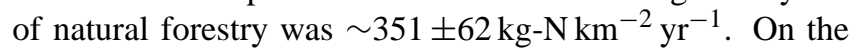
other hand, the extremely high nitrate yield of active farmland was $\sim 308,170 \pm 19241 \mathrm{~kg}-\mathrm{N} \mathrm{km}^{-2} \mathrm{yr}^{-1}$ due to overfertilization. The deconvolution computation technique is capable of tracing the mixed signals at the outlet back to the nitrate productions from varied land use patterns. It advances the application of river monitoring network. The typical values of nitrate yields can serve as a guideline for land
\end{abstract}

management. Comparing the nitrogen input and output, we found some nitrogen missing in the cycling which may indicate certain removal processes and we therefore suggest further study to be carried out to fully understand nitrogen cycling in subtropics.

\section{Introduction}

Nitrate export from diffuse sources (Burns et al., 1998; Boesch et al., 2001; Rabalais, 2002; De Vries et al., 2003) is a major cause of eutrophication and episodic acidification for inland aquatic systems and coastal zones (Vitousek et al., 1997; Crimo and McDonnell, 1997; Creed and Band, 1998; Galloway et al., 2003; Meader and Goldstein, 2003; Wellington and Driscoll, 2004). Resolving nutrient leaching rates of various diffuse sources may help watershed sustainability management maintaining required water quality and maximizing agricultural activity for food production. However, the contributions from various diffuse sources are difficult to identify owing to the spatial and temporal heterogeneity of hydrological processes and agricultural activities (D'Arcy and Carignan, 1997; Herlihy et al., 1998; Hooke, 1999; Johnson et al., 2000). Moreover, diffuse pollution sources are region-dependent and are related to different environmental settings and agricultural behaviors.

Stream nitrogen export has been recognized as highly correlated to the proportion of agricultural land in a catchment 
(Howarth et al., 2002). Previous studies in different countries and climate zones have addressed this issue. The list includes: Poor and McDonnell (2007) in Oregon, USA; Zhang et al. (2009) in the Han River, a major tributary of the Yangtze River in China; Ohrui and Mitchell (1998), Ogawa et al. (2006), and Tanaka and Suzuki (2009) in Japanese forested watersheds; Walton and Hunter (2009) at the Great Barrier Reef in Australia; and Rode et al. (2009) in central Germany. The mid to low latitude areas, where population and agricultural activities keep increasing, were predicted to be the hotspots for DIN (dissolved inorganic nitrogen, among which nitrate is the dominant species) export which occupies 2/3 of the global land-to-ocean $\mathrm{N}$ input (Dumont et al., 2005: Galloway et al., 1994). However, the observations of nitrogen fluxes in low-latitude areas and its controlling factors have not been well explored.

Southern Asian countries in the tropics and subtropics are characterized by rugged mountainous watersheds, heavy precipitation, and high population density. Among these countries, Taiwan is a subtropical mountainous island with the maximum elevation of $\sim 4000 \mathrm{~m}$ a.s.l. and $\sim 70 \%$ area is above $100 \mathrm{~m}$ a.s.l. The island-wide annual rainfall is approximately $2400 \mathrm{~mm}$, which is over 3 times of the global average (Legates, 1995). Annually, 3-5 typhoons invade Taiwan during June to October. The stream discharge during the wet season comprises $70-85 \%$ of annual total discharge. For a typical mountainous island, slope land cultivation is regarded as an inevitable way to support society. Over-fertilization becomes common due to farmers' concern of losing fertilizer because a high portion of the fertilizer applied during the summer growing season may be flushed away by heavy rainfall. In the past two decades, the government has made great efforts to rehabilitate the headwater environment in the central mountain belt to restore the water quality downstream.

This study investigated the spatial characteristics of nitrate concentrations and fluxes in mountainous watersheds with various gradients of agricultural activities. We also established a new method to determine the nitrate yield rate for each land use type. Our extensive observations of nitrate in a wide range of flow conditions interpreted the natural/anthropogenic factors in nitrogen export and provided information of land-use-associated nitrate yields. These observations can serve as a guideline for a better water resource and land management.

\section{Material and methods}

\subsection{Study site}

The Chi-Chia-Wan watershed in central Taiwan drains an area of $105 \mathrm{~km}^{2}$ and comprises rugged mountainous terrain with elevations from 1131 to $3882 \mathrm{~m}$ a.s.l. Two major tributaries, Yi-Ka-Wan Creek and You-Sheng Creek with drainage areas of 74 and $31 \mathrm{~km}^{2}$, converge into

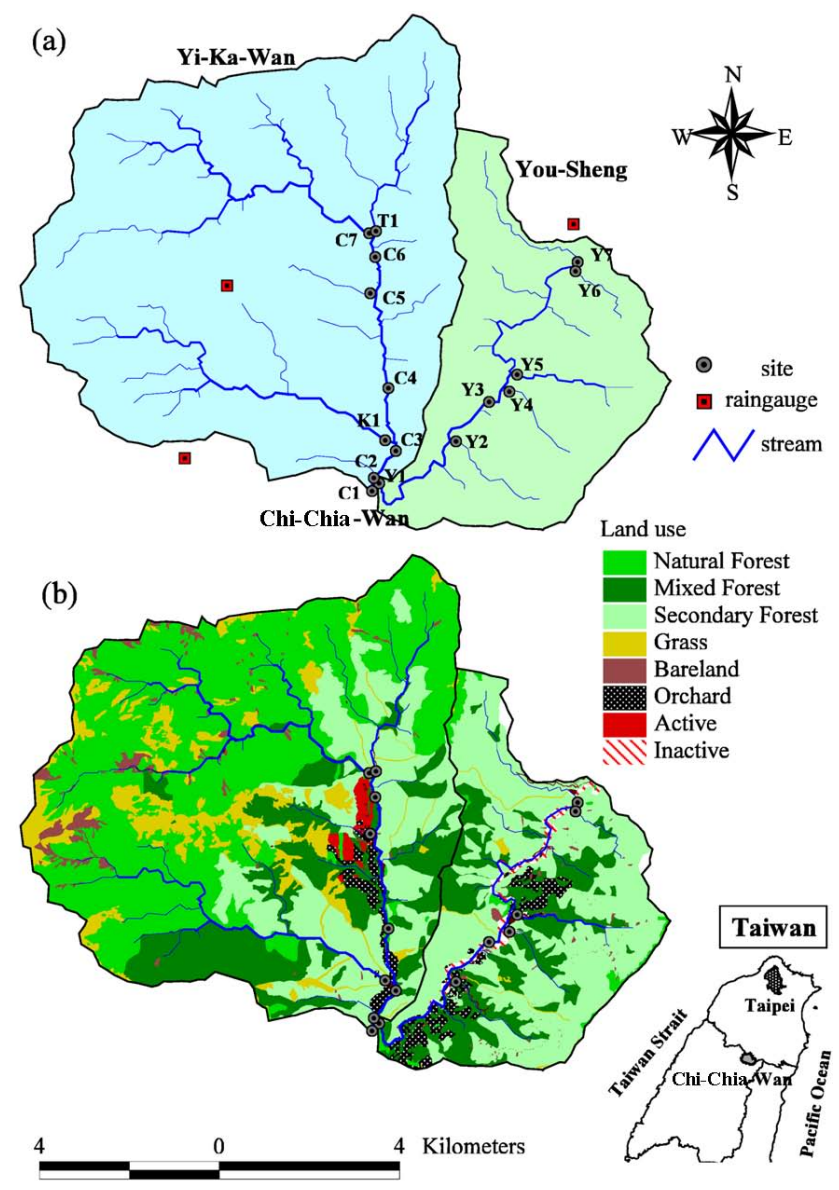

Fig. 1. Landscape (a) and land use pattern (b) in the study area.

Chi-Chia-Wan Creek. Two discharge gauges monitoring Chi-Chia-Wan Creek (C1) and You-Sheng Creek (Y1), and three rain gauges are maintained by the Taiwan Power Company nearby (Fig. 1a). Approximately $75 \%$ of the annual rainfall occurs in the wet season (May to October), in which tropical cyclones are the main contributor. The mean daily discharges averaged from 2000 to 2009 are $7.94 \mathrm{~m}^{3} \mathrm{~s}^{-1}$ for Chi-Chia-Wan and $2.41 \mathrm{~m}^{3} \mathrm{~s}^{-1}$ for You-Sheng Creek. The averaged daily discharges in the wet season are 11.80 and $4.07 \mathrm{~m}^{3} \mathrm{~s}^{-1}$, respectively. Notably, the peak flows may often exceed 20 times the mean daily discharge during the flood periods. The annual average air temperature is $15.8^{\circ} \mathrm{C}$, and the monthly average air temperatures in January and July were $4{ }^{\circ} \mathrm{C}$ and $23^{\circ} \mathrm{C}$ during $2000-2009$.

The studied watershed has attracted much attention because Yi-Ka-Wan Creek is now the only remaining habitat for the endangered Formosan landlocked salmon (Oncorhynchus masou formosanus) in the world. In this watershed, forest composed of Pinaceae (Pinus taiwanensis), Juglandaceae (Juglans cathayensis), Aceraceae (Acer serrulatum) and Betulaceae (Alnus formosana) covers $87 \%$ of the whole catchment (above $\mathrm{C} 1$ in Fig. 1a). The other land use 
types, including grass, bare land, orchard, active vegetable farms, and inactive vegetable farms, occupy the remaining $13 \%$ of the area. Unlike the single dominant land use landscape in America and Europe (Mayer et al., 2002; Rode et al., 2009; Rose et al., 2001), ,the land use pattern in the small mountainous catchment is mixed. The cultivated lands are mostly confined to the foothills and the riparian zones (Fig. 1b) due to the availability of water intake. This characteristic is often found in the Taiwan mountainous areas.

To conserve the landlocked salmon, the Taiwanese government began to expropriate the cultivated farms along YouSheng Creek in 2005. The expropriated vegetable farms were categorized as inactive farms in this study. On the other hand, "active farms" are designated to the currently growing farms. To explore the influence of land use patterns on nitrate yield, the entire watershed was divided into 16 nested catchments. All sampling sites are located at the outlet of sub-watersheds (Fig. 1). From the relatively pristine (C7, T1, and K1) to the intensively cultivated sub-watersheds (C5), different levels of human disturbance are involved. The basic landscape characteristics of those sampling sites are shown in Table 1, and the detailed descriptions of the land use pattern in each sub-watershed are listed in Table 2. Such a wide spectrum of land use combinations helps us to assess the land use impact on nitrogen output.

\subsection{Nitrate monitoring and measurement}

In this study, 16 sampling sites were set in the Chi-Chia-Wan catchment, of which 9 sites are located in Yi-Ka-Wan Creek and 7 sites in You-Sheng Creek covering the entire watershed. Biweekly (at C1, Y1, and K1) and monthly (other 13 stations) sampling schemes were conducted during 20072008. Additionally, intensive sampling ( $3 \mathrm{~h}$ interval) was conducted during Typhoon Sepat (16-19 August 2007) and Typhoon Krosa (4-7 October 2007) at stations C2, C7, Y1, and $\mathrm{K} 1$. The intensive sampling during high flow conditions helped construct a reliable concentration-discharge relationship covering various flows for examining the hydrological influence on nitrate export.

Water samples taken from streams were immediately filtered through $\mathrm{GF} / \mathrm{F}$ filters $(0.7 \mathrm{~mm})$, and the filtrate was frozen on site in liquid nitrogen and then kept in a freezer. Nitrate was determined by ion chromatography (IC), Dionex ICS-1500, with a detection limit of $0.01 \mathrm{mg}^{-1}$ (Welch et al., 1996). Three DIN (dissolved inorganic nitrogen) species $\left(\mathrm{NH}_{4}, \mathrm{NO}_{3}\right.$, and $\left.\mathrm{NO}_{2}\right)$ were measured and nitrate is the dominant species due to its mobilization feature. For $\mathrm{NO}_{2}$ and $\mathrm{NH}_{4}$, almost all of the samples were below the detection limit and then were ignored. Except for the dissolved nitrogen, particle-associated nitrogen might be an important component of nitrogen in mountainous rivers, especially in rivers influenced by agricultural activity. However, the narrow isotopic signature range and $\sim 4$ orders of magnitude in sediment export fluctuation during high flow conditions (Kao
Table 1. The basic landscape characteristics of the 16 sampling sites.

\begin{tabular}{lrccrc}
\hline $\begin{array}{l}\text { Site } \\
\text { ID }\end{array}$ & $\begin{array}{r}\text { Drainage } \\
\text { area } \\
\left(\mathrm{km}^{2}\right)\end{array}$ & $\begin{array}{r}\text { Average } \\
\text { slope } \\
(\%)\end{array}$ & $\begin{array}{r}\text { Average } \\
\text { elevation } \\
(\mathrm{m})\end{array}$ & $\begin{array}{r}\text { Max. flow } \\
\text { length } \\
(\mathrm{km})\end{array}$ & $\begin{array}{c}\text { Stream } \\
\text { type* }\end{array}$ \\
\hline Y7 & 4.34 & 55.8 & 2336 & 5.18 & $\mathrm{M}$ \\
$\mathrm{Y} 6$ & 2.07 & 53.6 & 2208 & 3.11 & $\mathrm{~T}$ \\
$\mathrm{Y} 5$ & 4.43 & 60.0 & 2287 & 4.06 & $\mathrm{~T}$ \\
$\mathrm{Y} 4$ & 2.81 & 57.1 & 2310 & 3.35 & $\mathrm{~T}$ \\
$\mathrm{Y} 3$ & 23.28 & 56.5 & 2216 & 11.46 & $\mathrm{M}$ \\
$\mathrm{Y} 2$ & 2.99 & 60.7 & 2259 & 3.92 & $\mathrm{~T}$ \\
$\mathrm{Y} 1$ & 30.92 & 56.8 & 2182 & 15.48 & $\mathrm{M}$ \\
\hline $\mathrm{T} 1$ & 11.31 & 72.3 & 2560 & 6.12 & $\mathrm{~T}$ \\
$\mathrm{C} 7$ & 25.36 & 76.9 & 2883 & 10.49 & $\mathrm{M}$ \\
$\mathrm{C} 6$ & 39.75 & 74.1 & 2735 & 11.93 & $\mathrm{M}$ \\
$\mathrm{C} 5$ & 1.59 & 57.9 & 2204 & 3.04 & $\mathrm{~T}$ \\
$\mathrm{C} 4$ & 48.66 & 71.4 & 2634 & 14.21 & $\mathrm{M}$ \\
$\mathrm{K} 1$ & 21.05 & 74.4 & 2577 & 10.80 & $\mathrm{~T}$ \\
$\mathrm{C} 3$ & 71.91 & 71.8 & 2596 & 16.32 & $\mathrm{M}$ \\
$\mathrm{C} 2$ & 74.03 & 71.4 & 2581 & 17.09 & $\mathrm{M}$ \\
$\mathrm{C} 1$ & 105.01 & 67.1 & 2463 & 17.13 & $\mathrm{M}$ \\
\hline
\end{tabular}

* "M" means the sampling sites located in main streams and "T" indicates the sites in tributaries. The horizontal line separates the You-Sheng and Yi-Ka-Wan subcatchment.

and Milliman, 2008); we can hardly separate agricultureassociated PN from the extraordinarily high sediment export sourced from typhoon-triggered landslides (Kao and Liu, 2000; Hilton et al., 2008). Therefore, this entire study focuses on nitrate, the predominant species of DIN export.

\subsection{Ungauged catchment discharge}

Discharge values are essential for estimating nitrate flux but impossible to measure for all sampling sites. A modified 3layer TOPMODEL was thus applied to estimate daily discharge for those ungauged sites. The model divides the vertical soil column into three layers: upper layer, middle layer, and bottom layer. Five hydrological processes and three runoff routings are considered including precipitation, interception, infiltration, percolation, and evapotranspiration. Based on the degree of saturation in the three layers, the surface flow, inter flow and base flow can be routed by the soil moisture deficit. Land use class was assumed to have no influence on water discharge because forest is predominant in the watershed $(90 \%)$. Parameterization was conducted separately for the Chi-Chia-Wan and You-Sheng catchments. Details of the model can be found in our previous modeling work (Huang et al., 2009). This model has been successfully applied to other mountainous watersheds in Taiwan (Huang et al., 2011a,b). Historical data during 2001-2005 on the Chi-Chia-Wan and You-Sheng catchments were used for calibration, and 2007-2008 data were used for validation.

The efficiency coefficient (EC) proposed by Nash and Sutcliffe (1970) was used to quantify the overall deviation 
Table 2. The land use composition (\%) within the 16 sampling sites.

\begin{tabular}{lrrrrrrrr}
\hline $\begin{array}{l}\text { Site } \\
\text { ID }\end{array}$ & $\begin{array}{r}\text { Natural } \\
\text { forest }\end{array}$ & $\begin{array}{r}\text { Mixed } \\
\text { forest }\end{array}$ & $\begin{array}{r}\text { Secondary } \\
\text { forest }\end{array}$ & Grass & $\begin{array}{r}\text { Bare } \\
\text { land }\end{array}$ & Orchard & $\begin{array}{r}\text { Active } \\
\text { farm }\end{array}$ & $\begin{array}{c}\text { Inactive } \\
\text { farm }\end{array}$ \\
\hline Y7 & 8.9 & 1.9 & 85.0 & 1.5 & 1.3 & 0.0 & 0.0 & 3.0 \\
Y6 & 0.0 & 10.3 & 88.5 & 0.0 & 0.9 & 0.0 & 0.0 & 0.6 \\
Y5 & 4.1 & 20.4 & 67.2 & 0.5 & 2.2 & 5.1 & 0.0 & 1.4 \\
Y4 & 0.9 & 24.9 & 71.2 & 0.8 & 1.0 & 0.4 & 0.0 & 0.7 \\
Y3 & 2.9 & 21.8 & 66.4 & 0.9 & 1.9 & 2.9 & 0.0 & 4.1 \\
Y2 & 0.2 & 23.1 & 70.5 & 1.1 & 1.8 & 2.6 & 0.0 & 0.1 \\
Y1 & 2.6 & 23.5 & 62.9 & 0.8 & 1.9 & 5.2 & 0.0 & 3.7 \\
\hline T1 & 67.8 & 2.2 & 26.8 & 2.7 & 0.4 & 0.0 & 0.0 & 0.0 \\
C7 & 76.6 & 3.5 & 4.2 & 11.7 & 3.5 & 0.0 & 0.0 & 0.0 \\
C6 & 66.9 & 4.4 & 15.0 & 10.1 & 2.4 & 0.0 & 0.7 & 0.0 \\
C5 & 1.1 & 46.1 & 9.7 & 17.2 & 1.2 & 11.6 & 13.1 & 0.0 \\
C4 & 54.9 & 11.6 & 17.4 & 10.7 & 2.2 & 1.3 & 1.3 & 0.0 \\
K1 & 47.8 & 22.5 & 19.7 & 7.6 & 2.2 & 0.1 & 0.0 & 0.0 \\
C3 & 50.7 & 15.2 & 19.2 & 10.1 & 2.2 & 1.2 & 0.9 & 0.0 \\
C2 & 47.4 & 15.9 & 21.8 & 9.7 & 2.0 & 1.7 & 1.0 & 0.0 \\
C1 & 35.7 & 17.8 & 32.7 & 7.4 & 2.1 & 2.5 & 1.4 & 0.5 \\
\hline
\end{tabular}

between the simulated and observed hydrographs. An EC of 1 indicates a perfect match.

$\mathrm{EC}=1-\frac{\sum_{i=1}^{N}\left(Q_{\mathrm{s}, i}-Q_{\mathrm{o}, i}\right)^{2}}{\sum_{i=1}^{N}\left(Q_{\mathrm{o}, i}-\bar{Q}_{\mathrm{o}}\right)^{2}}$.

The $\mathrm{EC}_{\log }$, the logarithmic Nash-Sutcliffe efficient, was used to quantify the similarity specifically for low flow condition (e.g. Güntner et al., 1999; De Smedt et al., 2000).

$\mathrm{EC}_{\log }=1-\frac{\sum_{i=1}^{N}\left(\log \left(Q_{\mathrm{s}, i}\right)-\log \left(Q_{\mathrm{o}, i}\right)\right)^{2}}{\sum_{i=1}^{N}\left(\log \left(Q_{\mathrm{o}, i}\right)-\overline{\log \left(Q_{\mathrm{o}}\right)}\right)^{2}}$.

In Eqs. (1) and (2), $Q_{\mathrm{o}, i}$ is the observed discharge at day $i, Q_{\mathrm{s}, i}$ is the simulated discharge, and $N$ is the total number of time steps during the evaluated period. Based on the two measures, a set of promising parameters can be retrieved. The parameterized model was applied for ungauged stations.

\subsection{Nitrate flux estimation for subcatchment outlet}

Based on the monitored nitrate concentration and simulated discharges, we estimated the $\mathrm{NO}_{3}-\mathrm{N}$ fluxes. However, there is no simple and easy way to estimate flux accurately due to several factors, such as sampling frequency, hydrological behaviors, and hydrologic response (Lee et al., 2007). Therefore, four commonly used methods (i.e. linear interpolation (LI), global mean (GM), flow weighted (FW), and the rating curve (RC) method) were applied in this study to estimate annual flux. The mean values of the four flux methods were used for further yield computation to avoid arbitrary errors caused by the aforementioned factors.

The linear interpolation (LI) method which interpolates the unsampled daily nitrate concentrations by two adjacent actually measured nitrate concentrations, as shown in Eq. (3) (Moatar and Meybeck, 2005).

FLUX $=m \sum_{j=1}^{T} C_{j}^{\mathrm{int}} \times Q_{j}$

where FLUX is annual $\mathrm{NO}_{3}-\mathrm{N}$ load $\left[\mathrm{kg} \mathrm{yr}^{-1}\right]$; $C_{j}^{\text {int }}$ is the $\mathrm{NO}_{3}-\mathrm{N}$ concentration on $j$-th day linearly interpolated between two measured samples $\left[\mathrm{mg} \mathrm{l}^{-1}\right] ; Q_{j}$ is the daily discharge derived from TOPMODEL $\left[\mathrm{m}^{3} \mathrm{~s}^{-1}\right] ; m$ is the conversion factor to convert the calculated values into a specific unit $\left[\mathrm{kg} \mathrm{yr}^{-1}\right] . T$ stands for the number of days of the studied period, which is a year for this study.

The global mean (GM) method multiplies the average concentration of all samples by the total discharge within the study period, as shown in Eq. (4) (Birgand et al., 2010).

FLUX $=m \frac{\sum_{i=1}^{n} C_{i}}{n} \times Q_{\mathrm{t}}$.

$C_{i}$ is the $\mathrm{NO}_{3}-\mathrm{N}$ concentration of the water sample $\left[\mathrm{mg} \mathrm{l}^{-1}\right]$; $Q_{\mathrm{t}}$ is the annual total discharge $\left[\mathrm{m}^{3} \mathrm{yr}^{-1}\right]$; and $n$ is the number of water samples in a year. This method does not yet take the hydrological responses into account.

Considering the hydrological responses, the flow weighted (FW) method, which weights the concentration by discharge, 
is widely used, as shown in Eq. (5). Annual nitrate flux equals the annual discharge volume multiplied by the flowweighted nitrate concentration.

FLUX $=m \frac{\sum_{i=1}^{n} C_{i} Q_{i}}{\sum_{i=1}^{n} Q_{i}} \times Q_{\mathrm{t}}$.

$Q_{i}\left[\mathrm{~m}^{3} \mathrm{~s}^{-1}\right]$ is the corresponding discharge on the discrete sampling day.

The rating curve $(\mathrm{RC})$ method has been widely used in small mountainous rivers with highly fluctuating hydrodynamic range (Kao and Liu, 2000; Kao et al., 2004; Kao and Milliman, 2008), and is discussed comprehensively by Kao et al. (2005). This method aims to construct a regression equation between discrete observations and corresponding discharges with a power function, $C=a Q^{b}$, which represents the hydrological influence on transport. The parameter $b$ denotes the hydrological influence. A larger $b$ value $(>0)$ indicates enhanced concentration with increasing discharge. By contrast, a smaller $b$ value reflects the dilution effect because the concentration decreases with the increase of $Q$. We assume the relationship works throughout the entire year. After obtaining the rating relation, we may estimate the concentration and therefore, the flux for non-measured days, by introducing continuous daily water discharge into the rating relation.

FLUX $=m \sum_{j=1}^{T} Q_{j} C_{j}=m \sum_{j=1}^{T} a Q_{j}^{b+1}$

where $Q_{j}\left[\mathrm{~m}^{3} \mathrm{~s}^{-1}\right]$ is the daily water discharge rate; $C_{j}$ $\left[\mathrm{mg} \mathrm{l}^{-1}\right]$ is an estimated constituent concentration on the $j$ th day. The discharges in the above equations are all derived from the TOPMODEL simulation.

To properly transfer discrete concentrations to annual flux with continuous water discharge record in this fashion is a state-of-the-art method. The estimated fluxes from the limited number of observations are always somewhat uncertain and difficult to verify. Hence, we applied the monthly sampling scheme, which was implemented at most of the sites, onto the intensive monitoring sites (K1, Y1 and $\mathrm{C} 1)$ to illustrate the potential uncertainty of sampling frequencies on flux estimation.

\subsection{Nitrate yields of landuse types}

Many factors, including topography, deforestation, urbanization, and hydrodynamics may alter water chemistry (Rose and Peters, 2009; Swank et al., 2001). For nitrate export, the land use pattern and land use proportions are the dominant factors. Therefore, the EPA proposed the PLOAD model, which suggests empirical yield for each land use type. Based on this look-up table, authorities can estimate the nitrate export for specific purposes (EPA, USA, 2001). However, such a fixed empirical look-up table may not be available or proper for different regional settings. In this study, we derived the land-use-associated nitrate yields based on the land use pattern and the observed nitrate fluxes through the inversed PLOAD calculation. Our inversed PLOAD method can deconvolute the nitrate yield of the specific land use within the catchment. It is assumed that each type of land use can export $k \mathrm{~kg}-\mathrm{NO}_{3}-\mathrm{N} \mathrm{km}^{-2} \mathrm{yr}^{-1}$ without considering the complicated in-stream processes. This assumption may be satisfactory when the stream length is short and the flow velocity is fast. From an annual perspective, the annual nitrate flux can be equal to the summed product of the yields and the corresponding land use areas, as shown in Eq. (7).

FLUX $=\sum_{i=1}^{n} k_{i} \times A_{i}$

where FLUX is the annual flux/load $\left[\mathrm{kg} \mathrm{yr}^{-1}\right] ; \quad k_{i}$ $\left[\mathrm{kg} \mathrm{km}^{-2} \mathrm{yr}^{-1}\right]$ and $A_{i}\left[\mathrm{~km}^{2}\right]$ are the yield and the area for land use $i$. The 8 yield factors can be obtained from the 16 algebraic equations. However, to consider the uncertainties from the assumptions, a trial and error procedure was applied to estimate the yield factor using RMSE (root mean square error) as a performance measure. 300000 yield factor combinations (each combination includes 8 yield factors) were generated to fit the $\mathrm{NO}_{3}-\mathrm{N}$ fluxes at the sub-catchment outlets for 2007 and 2008, separately. The combinations, which simultaneously minimized the 2007 and 2008 RMSE data, were selected to form the posterior distributions of the yield factors. This derived optimal estimation should approximate the representative yield of each land use category over wide spatial and temporal scales. This yield factor, similar to a land cover indicator, is the most important component for the assessment of the pollution in water bodies from non-point sources (Munaf et al., 2005; Lane et al., 2006).

\section{Results and discussion}

\subsection{Discharge simulation}

The simulated discharge based on the calibrated parameter sets in $\mathrm{C} 1$ and $\mathrm{Y} 1$ are shown in Fig. 2. The simulation satisfactorily imitated the monitored discharge. The performance measures of $\mathrm{EC}$ and $\mathrm{EC}_{\log }$ were 0.89 and 0.90 for ChiChia-Wan Creek and 0.83 and 0.84 for You-Sheng Creek, respectively. For the validation period (2007-2008), the two calibrated parameter sets were applicable with the performance measures of 0.84 and 0.89 for Chi-Chia-Wan (C1), and 0.81 and 0.83 for You-Sheng (Y1). In C1, both the peak flow and low flow could be accurately simulated. In Y1, the peak flow was also accurately estimated, whereas the low flow was a little overestimated. The overestimated low flow in the simulation may result from agricultural activities. Unlike irrigation on large river floodplains, where water is extracted from groundwater/impoundment, in this study area, 

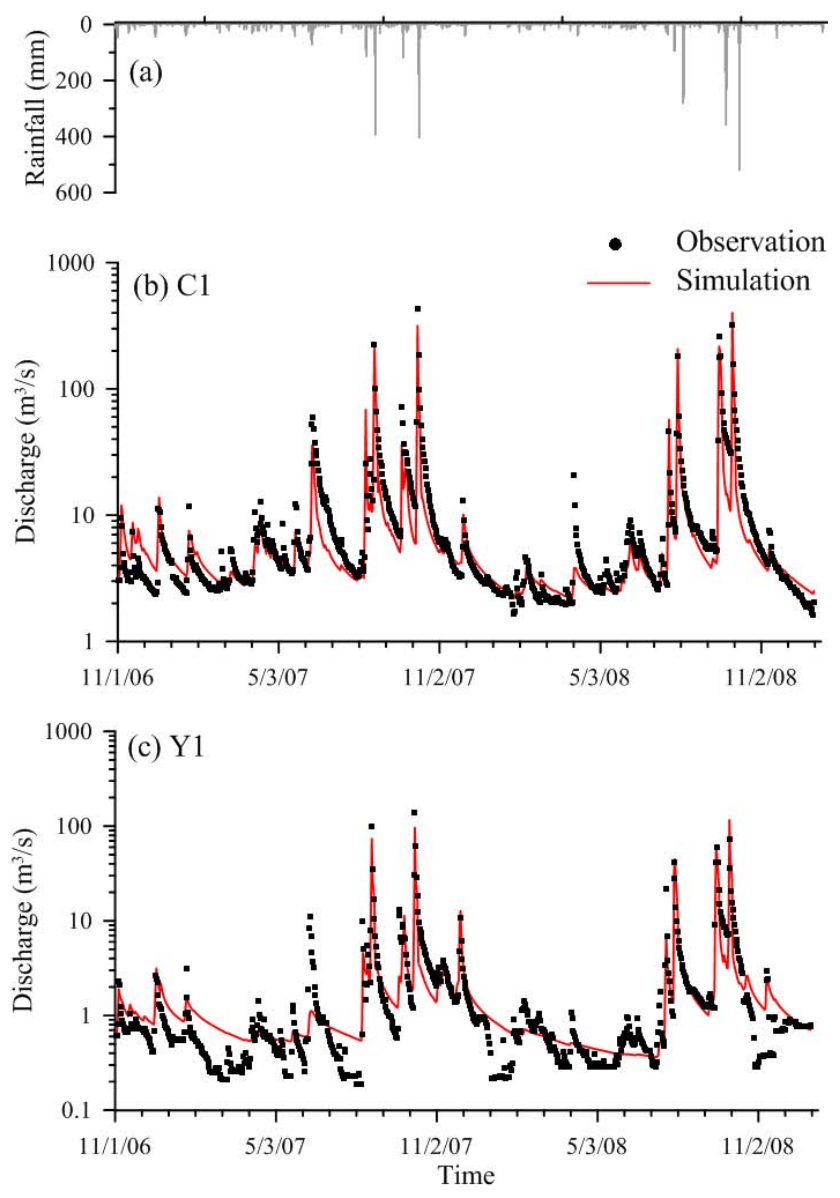

Fig. 2. The time series data of rainfall and discharge during the study period. The rainfall hyetograph from 1 November 2006 to 31 December 2008 is shown in panel (a). The observed and simulated discharge in $\mathrm{C} 1$ and $\mathrm{Y} 1$ are shown in panels (b) and (c), respectively. The black dots represent the observed discharge and the red lines stand for the simulation.

water is withdrawn directly from the stream which results in a lower water level than in the simulation (Huang et al., 2011b). Nevertheless, the comparable results between the observation and calibration/validation demonstrate the reliability in discharge simulation and the confidence in the parameter sets, which are the basis for estimating discharge in the ungauged sub-catchments.

\section{2 $\mathrm{NO}_{3}-\mathrm{N}$ concentration pattern}

The time series of $\mathrm{NO}_{3}-\mathrm{N}$ concentration (including two highfrequency sampling campaigns during typhoon periods) and simulated discharge at cultivated Y1 (Fig. 3a) and pristine K1 (Fig. 3b) stations are shown as examples in Fig. 3. The nitrate concentration varies concomitantly with the hydrograph. The seasonality of nitrate concentration is obvious at both stations, but smaller at $\mathrm{K} 1$. The $\mathrm{NO}_{3}-\mathrm{N}$ concentration at $\mathrm{Y} 1$ is gently decreasing during the study period. This overall decreasing trend might be attributed to the decline of agricultural activities since 2005. Using observations from two flood events (Fig. 3c and d), we illustrated a potential nitrate leaching and runoff generation mechanism. At cultivated Y1 station, one single data point of high nitrate concentration appeared on the rising limb of the hydrograph in each flood case. This high concentration was very likely caused by infiltration of excess runoff that washed over cultivated area (Poor and McDonnell, 2007). By contrast, this phenomenon was not observed at $\mathrm{K} 1$, which is relatively pristine.

During the two flood events, both cultivated and natural sub-catchments showed that the peak concentration followed the peak discharge by a few hours. The couple of hours lag time between discharge and concentration peaks might indicate the predominance of nitrate-replete water from groundwater discharge during recession limb, including those flowing through the cultivated riparian zones. The subterranean old water might be squeezed out rapidly within only a few days. In fact, via careful examination on the flood peaks, we found a small but short-term decrease in discharge around the peak in both flood cases; meanwhile nitrate concentration increased synchronously. Such synchronicity might reflect a fast decrease in fractional contribution from surface component with nitrate-deplete water.

There were three consecutive typhoons in 40 days (we monitored the first and third typhoons). We observed a lower $\mathrm{NO}_{3}$ concentration but higher runoff depth and higher cumulative $\mathrm{N}$ export in the third event in both watersheds. Hydrological factors seemed to dominate the export even with decreased concentration. The nitrogen storage in the soil/watershed probably had not been depleted in the third event in relatively pristine or cultivated watersheds. These results implied that the storage was large enough to support frequent flush-out export. Although the fertilizer carry-over from the dry season may provide a peak concentration in the wet season, the fertilizer is mainly applied during summer/wet season. To understand nitrate concentration variation, the transport dynamics among nitrogen pools and the rate of inventory accumulating/diminishing over time, further long-term investigation should be performed to explore the nitrogen budget changes.

The $\mathrm{NO}_{3}-\mathrm{N}$ concentrations of the 16 sites are shown in Table 3 and Fig. 4. The sub-catchments can be classified into three distinct types according to the $\mathrm{NO}_{3}-\mathrm{N}$ concentration and the land use pattern. T1, C7 and $\mathrm{K} 1$ were classified into the first type, relatively pristine catchment where the $\mathrm{NO}_{3}-\mathrm{N}$ concentrations ranged from $\sim 0.11-0.17 \mathrm{mg}^{-1}$ and $\sim 0.10$ $0.16 \mathrm{mgl}^{-1}$ in the dry and wet season, respectively. Such concentrations are comparable with other pristine catchments around the world (Dumont et al., 2005). In terms of land use patterns, $\mathrm{C} 6, \mathrm{C} 4,-\mathrm{C} 1$, and $\mathrm{Y} 7-\mathrm{Y} 1$ were the second type, moderately cultivated catchment. In those catchments, the $\mathrm{NO}_{3}-\mathrm{N}$ concentrations varied between $\sim 0.38$ $1.80 \mathrm{mg} \mathrm{l}^{-1}$ and $\sim 0.46-1.87 \mathrm{mg} \mathrm{l}^{-1}$ in the dry and wet seasons, respectively. Those catchments were characterized 

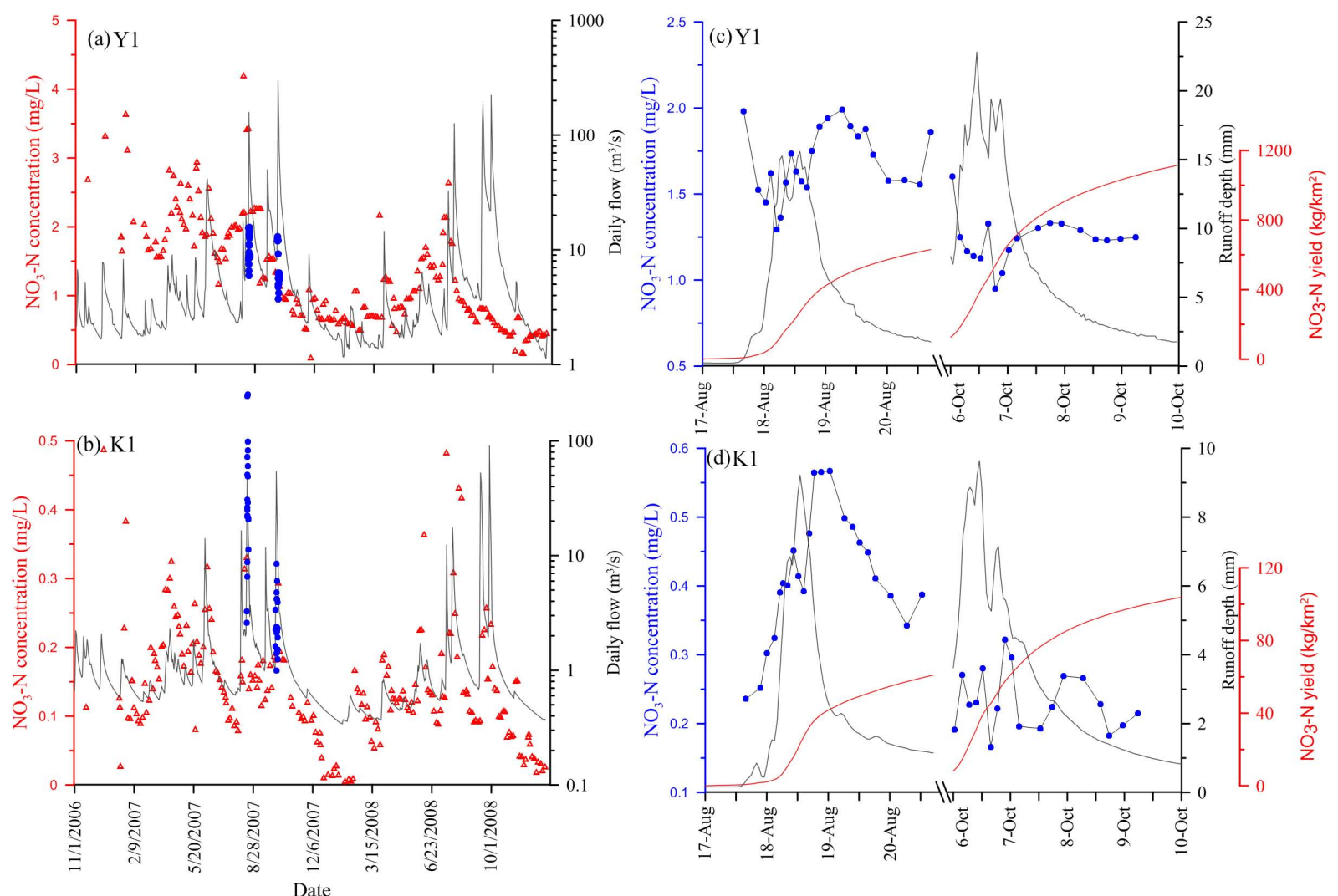

Fig. 3. The observed $\mathrm{NO}_{3}-\mathrm{N}$ concentration and the simulated discharge during the study period. The simulated discharge (black solid lines), $\mathrm{NO}_{3}-\mathrm{N}$ concentration from biweekly samples (red dots) and typhoons (blue dots) in Y1 are shown in panel (a). The hydrograph (black solid lines), $\mathrm{NO}_{3}-\mathrm{N}$ concentration (black line with blue dots), and cumulative nitrate flux (red lines) for the two typhoon events in Y1 are shown in panel (c). The same symbols for K1 station are shown in panels (b) and (d).

by a few agricultural activities (proportion of agricultureassociated land, including orchard, active and inactive farms, were approximately $0.6 \sim 8.9 \%$ of each sub-catchment). C5, the intensively cultivated catchment, had the highest nitrate concentration with the values of 15.45 and $10.97 \mathrm{mgl}^{-1}$ in the dry and wet season, respectively. No matter whether in the dry or wet season, the measured nitrate concentrations were all positively correlated with the proportion of agriculture-associated land in the sub-catchments $(r=0.93$, $p \ll 0.01$ for dry season; $r=0.94, p \ll 0.01$ for wet season) of the Yi-Ka-Wan and You-Sheng watersheds,

\section{3 $\mathrm{NO}_{3}-\mathrm{N}$ fluxes at the catchment outlets}

The relationship between $\mathrm{NO}_{3}-\mathrm{N}$ fluxes versus discharge is illustrated in Fig. 5. Generally, the $\mathrm{NO}_{3}-\mathrm{N}$ fluxes were positively correlated to discharge among all sub-catchments (Table 4). In power function fitting, we discovered that the $R^{2}$ values ranged from $0.59-0.89$. The coefficient $a$, indicating the background flux when discharge was low, was extremely high at C5. By contrast, the pristine catchments, like C7, T1, and K1 had the lower values of $a$ coefficient. The coefficient $b$ revealed the hydrological controls such as enhancemen and dilution effect ... etc. For most of the 16 sites, the $\mathrm{NO}_{3}-\mathrm{N}$ fluxes increased with the elevation of discharge $(b>1)$. However, a distinct dilution effect could be found in the Y1, Y2, and C5 sub-catchments $(b<1)$. The coefficient $b$ slightly decreased with the increase of agriculture-associated land. This phenomenon deserves further research but is not the focus in this study. For the specific $\mathrm{NO}_{3}-\mathrm{N}$ fluxes (normalized by drainage area), the pristine catchments (Fig. 5h,i, and $\mathrm{m}$ ) were approximately $0.1 \mathrm{~kg} \mathrm{day}^{-1} \mathrm{~km}^{-2}$ as the discharge was low. Even during the high flow period, the specific $\mathrm{NO}_{3}-\mathrm{N}$ fluxes were rarely over $100 \mathrm{~kg} \mathrm{day}^{-1} \mathrm{~km}^{-2}$. For moderately cultivated catchments, such as $\mathrm{Y} 7, \mathrm{Y3}$, and $\mathrm{C} 1$ (Fig. 5a,e, and p), the specific $\mathrm{NO}_{3}-\mathrm{N}$ fluxes ranged from 0.1 to $100 \mathrm{~kg} \mathrm{day}^{-1} \mathrm{~km}^{-2}$. We infer that the specific $\mathrm{NO}_{3}-\mathrm{N}$ flux would exceed $100 \mathrm{~kg} \mathrm{day}^{-1} \mathrm{~km}^{-2}$ if deluge occur. For the intensively cultivated catchment, C5, the specific $\mathrm{NO}_{3}-\mathrm{N}$ fluxes reached $300 \mathrm{~kg} \mathrm{day}^{-1} \mathrm{~km}^{-2}$ even when there was no typhoon invasion.

The $\mathrm{NO}_{3}-\mathrm{N}$ yields derived from the four methods (linear interpolation, global mean, flow weighted, and rating curve) at the catchment outlets for 2007 and 2008 are shown in Table 5. Generally the RC-derived $\mathrm{NO}_{3}-\mathrm{N}$ yields were inconsistent with those from the other methods, while the 

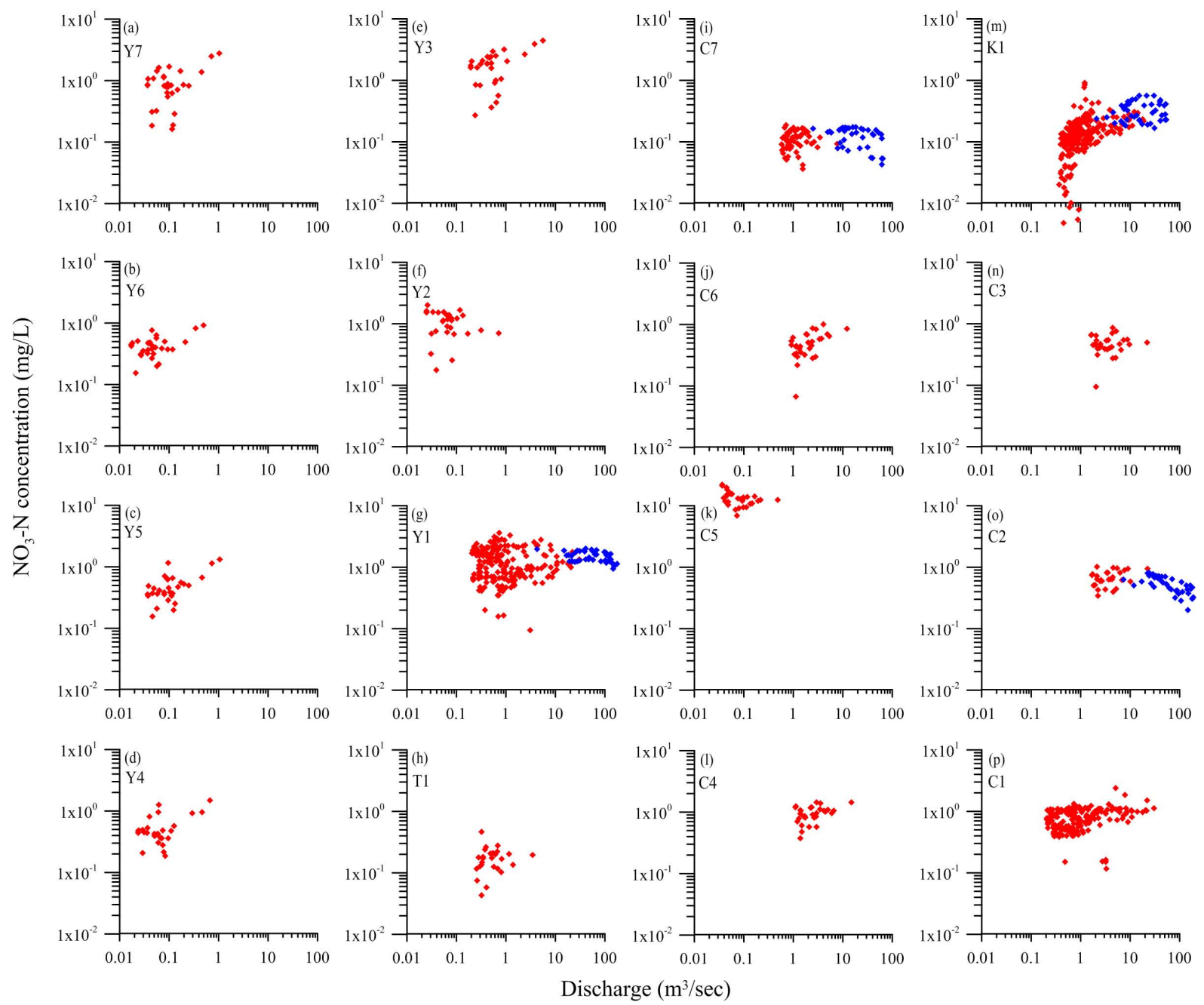

Fig. 4. The relationship between the monitored $\mathrm{NO}_{3}-\mathrm{N}$ concentration (y-axis) and the daily discharge (x-axis) on the sampling date over the entire sampling sites. The blue circles indicate the typhoon samples.

GM-derived fluxes particularly tended to have lower estimates. The RC-derived estimates fluctuated more because the RC method strongly relies on whether the samples cover the discharge spectrum. We did not exclude this method because previous studies (Kao et al., 2005; Kao and Milliman, 2008) have demonstrated the applicability of the RC method for small rivers with a good C-Q relationship. Notably, the LI method is suitable for estimating nitrate export in large rivers (David and Gentry, 2000; Moatar and Meybeck, 2005). Another controlling factor on flux calculation is sampling frequency. Here, monthly sampling schemes were applied on the sites, $\mathrm{Y} 1, \mathrm{~K} 1$, and $\mathrm{C} 1$ sub-catchments where intensive monitored data (Table 6) were available. We found that the calculated yields agreed creditably with the "best" yields derived from biweekly sampling scheme regardless of which estimation method is used (except the RC method). The sampling frequency may be the secondary factor for calculating dissolved matter fluxes in our study area.

\subsection{Comparison of $\mathrm{NO}_{3}-\mathrm{N}$ fluxes among other catchments}

Generally, the annual $\mathrm{NO}_{3}-\mathrm{N}$ yields of the 16 sub-catchments ranged over two orders of magnitude from $\sim 261-$ $45275 \mathrm{~kg} \mathrm{~km}^{-2} \mathrm{yr}^{-1}$, which corresponded to the agricultureassociated area $(r=0.93, p \ll 0.01$ for $2007 ; \quad r=0.91$, $p \ll 0.01$ for 2008). For relatively pristine catchments, the annual $\mathrm{NO}_{3}-\mathrm{N}$ export was around $\sim 238-1018 \mathrm{~kg} \mathrm{~km}^{-2} \mathrm{yr}^{-1}$ with an average of $585 \mathrm{~kg} \mathrm{~km}^{-2} \mathrm{yr}^{-1}$. For moderately cultivated catchments, the annual export was $\sim 628-$ $6526 \mathrm{~kg} \mathrm{~km}^{-2} \mathrm{yr}^{-1}$ with an average of $2327 \mathrm{~kg} \mathrm{~km}^{-2} \mathrm{yr}^{-1}$. With intensive agricultural activities, like $\mathrm{C} 5$, the $\mathrm{NO}_{3}-\mathrm{N}$ yield reached to an average of $40827 \mathrm{~kg} \mathrm{~km}^{-2} \mathrm{yr}^{-1}$, ranging from $28988-48914 \mathrm{~kg} \mathrm{~km}^{-2} \mathrm{yr}^{-1}$. Compared to the other catchments around the world (Table 7), the $\mathrm{NO}_{3}-\mathrm{N}$ export is $\sim 58-4000 \mathrm{~kg}-\mathrm{N} \mathrm{km}^{-2} \mathrm{yr}^{-1}$ from pristine to intensive agricultural catchments in USA (David et al., 1997; Mayer 

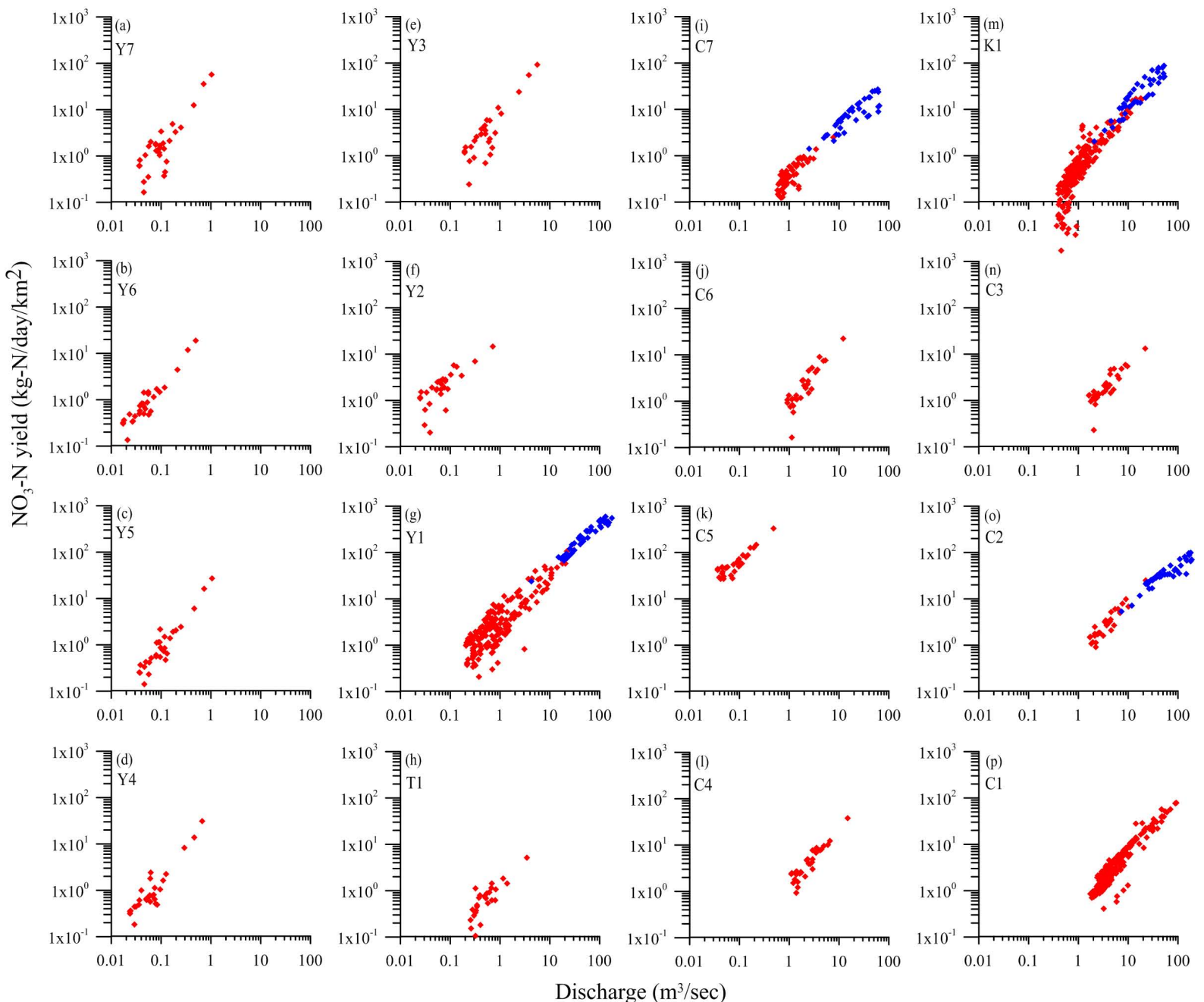

Fig. 5. The relationship between the specific $\mathrm{NO}_{3}-\mathrm{N}$ flux (y-axis) versus the daily discharge (x-axis) among the 16 sites. The blue circles stand for the typhoon samples.

et al., 2002; Sobota et al., 2009). In Germany, pristine catchments export $\sim 400 \mathrm{~kg}-\mathrm{N} \mathrm{km}^{-2} \mathrm{yr}^{-1}$ (Langusch et al., 2002), while catchments with larger arable area export 1850 $4120 \mathrm{~kg}-\mathrm{N} \mathrm{km}^{-2} \mathrm{yr}^{-1}$ (Rode et al., 2009). As for Australia, the average export from the pristine catchments is approximately $284 \mathrm{~kg}-\mathrm{N} \mathrm{km}^{-2} \mathrm{yr}^{-1}$, yet the slightly cultivated land would cause $\mathrm{NO}_{3}-\mathrm{N}$ export as high as $2304 \mathrm{~kg}-\mathrm{N} \mathrm{km}^{-2} \mathrm{yr}^{-1}$ (Hunter et al., 2008). In subtropical mountainous pristine areas of our study, the nitrate export is much higher and the proportion of agricultural land is relatively smaller. Although abundant precipitation might explain the high nitrate export from the pristine and moderately cultivated catchments, the effect of fertilizer application should be clarified.

Sub-catchment C5 is a good example with which to demonstrate the effect of fertilizer application due to its large share of agricultural-associated land. The intensive agricultural activities elevated the $\mathrm{NO}_{3}-\mathrm{N}$ yield over 70 times higher than our pristine catchments and 10 times higher than the values reported in the USA. In eastern central Illinois, USA, almost the whole watershed is used for row crop production, primarily corn rotated with soybean. The long-term average of $\mathrm{NO}_{3}-\mathrm{N}$ yield is $\sim 3000$ to $4000 \mathrm{~kg}-\mathrm{N} \mathrm{km}^{-2} \mathrm{yr}^{-1}$ (Kalita et al., 2007). At our C5 sub-catchment, cabbage is the primary crop in the active farms. It takes around 60 days to harvest. According to farmers' guidebook, the agency recommended dose is $200-300 \mathrm{~kg}-\mathrm{N} / \mathrm{ha} / \mathrm{batch}$, which can provide up to $\sim 40000 \mathrm{~kg}$ cabbage $/ \mathrm{ha} / \mathrm{batch}$. A total of $2-3$ round/yr of planting will be implemented depending on the market price. However, the farmers in Taiwan usually fertilize $\sim 1250 \mathrm{~kg}-\mathrm{N} / \mathrm{ha} / \mathrm{batch}$ to $\sim 3750(1250 \times 3) \mathrm{kg}-$ $\mathrm{N} \mathrm{ha}^{-1} \mathrm{yr}^{-1}$ (could be even more because the farmers sometimes grow green onion after the cabbage season; Peng et al., 2007), which is approximately 25 times higher than the corn field in the United States $\left(\sim 100-200 \mathrm{~kg}^{-} \mathrm{N} \mathrm{ha}^{-1} \mathrm{yr}^{-1}\right.$, David et al., 1997). The over-fertilization is understandable because the farmers anticipate a substantial flush away by heavy rainfall and typhoons. If we assume a maximum vegetation uptake of $\sim 750 \mathrm{~kg}^{-N_{h a}} \mathrm{yr}^{-1}(=250 \times 3)$ by the 
Table 3. The sampling numbers in each site, and the mean, standard deviation, maximum and minimum of the sampled $\mathrm{NO}_{3}-\mathrm{N}$ concentration in the wet and dry seasons.

\begin{tabular}{llrrrrrr}
\hline \multirow{2}{*}{ Site } & Sample & \multicolumn{2}{c}{ Dry season $\left(\mathrm{mg} \mathrm{l}^{-1}\right)$} & & \multicolumn{2}{c}{ Wet season $\left(\mathrm{mg}^{-1}\right)$} \\
\cline { 3 - 4 } \cline { 6 - 7 } ID & number & Mean \pm Stdev & Max/Min & & Mean \pm Stdev & Max/Min \\
\hline Y7 & 30 & $1.03 \pm 0.42$ & $1.62 / 0.19$ & & $0.88 \pm 0.76$ & $3.07 / 0.16$ \\
Y6 & 29 & $0.38 \pm 0.08$ & $0.49 / 0.20$ & & $0.49 \pm 0.21$ & $0.82 / 0.15$ \\
Y5 & 30 & $0.40 \pm 0.15$ & $0.70 / 0.20$ & & $0.61 \pm 0.33$ & $1.16 / 0.16$ \\
Y4 & 29 & $0.44 \pm 0.18$ & $0.81 / 0.19$ & & $0.64 \pm 0.39$ & $1.25 / 0.21$ \\
Y3 & 29 & $1.80 \pm 0.81$ & $2.40 / 0.44$ & & $1.87 \pm 1.25$ & $3.89 / 0.27$ \\
Y2 & 29 & $1.07 \pm 0.48$ & $1.60 / 0.18$ & & $1.10 \pm 0.44$ & $2.00 / 0.33$ \\
Y1 & $213(44)^{*}$ & $1.09 \pm 0.77$ & $3.63 / 0.09$ & & $1.44 \pm 0.60$ & $4.19 / 0.41$ \\
\hline T1 & 27 & $0.17 \pm 0.09$ & $1.39 / 0.04$ & & $0.16 \pm 0.03$ & $0.21 / 0.00$ \\
C7 & $60(41)$ & $0.11 \pm 0.03$ & $1.15 / 0.02$ & & $0.10 \pm 0.03$ & $0.15 / 0.04$ \\
C6 & 30 & $0.43 \pm 0.16$ & $0.87 / 0.07$ & & $0.58 \pm 0.23$ & $1.01 / 0.22$ \\
C5 & 30 & $15.45 \pm 3.39$ & $22.12 / 11.64$ & & $10.97 \pm 2.07$ & $14.15 / 0.69$ \\
C4 & 30 & $0.91 \pm 0.25$ & $1.45 / 0.38$ & & $1.00 \pm 0.29$ & $1.44 / 0.47$ \\
K1 & $217(43)$ & $0.16 \pm 0.15$ & $0.91 / 0.01$ & & $0.16 \pm 0.06$ & $0.93 / 0.07$ \\
C3 & 30 & $0.50 \pm 0.18$ & $0.86 / 0.09$ & & $0.46 \pm 0.12$ & $0.76 / 0.15$ \\
C2 & $29(44)$ & $0.67 \pm 0.16$ & $1.01 / 0.43$ & & $0.68 \pm 0.21$ & $0.96 / 0.20$ \\
C1 & 218 & $0.72 \pm 0.23$ & $1.34 / 0.12$ & & $0.82 \pm 0.32$ & $2.38 / 0.15$ \\
\hline
\end{tabular}

* The number in parentheses indicates the typhoon samples.

cabbages, there will be $\sim 3000 \mathrm{~kg}-\mathrm{N} \mathrm{ha}^{-1} \mathrm{yr}^{-1}$ unused fertilizer remained in the farm. Expectedly, at least a small portion of the fertilizer will keep accumulating in the soil and hence elevate the $\mathrm{N}$ yield.

\section{5 $\quad \mathrm{NO}_{3}-\mathrm{N}$ yield from land use classes}

Through the inversed PLOAD method, the optimized $\mathrm{NO}_{3}$ $\mathrm{N}$ yields for individual land uses are shown in Table 8 and Fig. 6. Based on the $\mathrm{NO}_{3}-\mathrm{N}$ yields derived from four methods at the catchment outlets in two years, four sets of land use-associated $\mathrm{NO}_{3}-\mathrm{N}$ yield combinations are derived (Fig. 6). Although there were some differences among the four methods, the $\mathrm{NO}_{3}-\mathrm{N}$ yields for each land use derived from the inversed method are consistent. Besides, the simulated $\mathrm{NO}_{3}-\mathrm{N}$ yield for each site promisingly agreed with the yields observed in both years (Fig. 7), indicating the representativeness of the $\mathrm{NO}_{3}-\mathrm{N}$ yield for 8 land use classes. It demonstrates the feasibility of the inversed PLOAD method in estimating the individual land use yields. As expected, the natural areas and forests held the lowest yield at $351-1064 \mathrm{~kg}-\mathrm{N} \mathrm{km}^{-2} \mathrm{yr}^{-1}$, which is in accordance with the nitrate yield at the pristine catchments. The bare land and grass had the medium value $\left(\sim 2008-2806 \mathrm{~kg}-\mathrm{N} \mathrm{km}^{-2} \mathrm{yr}^{-1}\right)$. As for the impacts of agricultural activities, the orchard yielding $5456 \pm 290 \mathrm{~kg}$ $\mathrm{N} \mathrm{km}^{-2} \mathrm{yr}^{-1}$ (over 5 to 10 times higher than the forest) was one of the nitrate diffuse sources. The yield of the active farmland, approximately $308170 \pm 19241 \mathrm{~kg}-\mathrm{N} \mathrm{km}^{-2} \mathrm{yr}^{-1}$, was extremely high yet comprehensible in view of

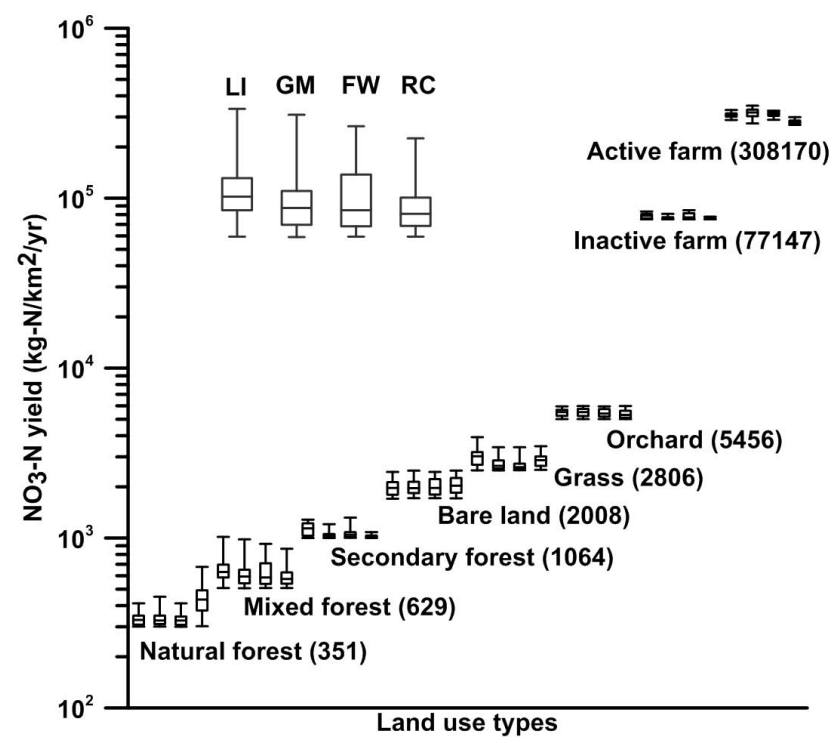

Fig. 6. The landuse-associated $\mathrm{NO}_{3}-\mathrm{N}$ yields. Four box-whisker plots for each landuse type stand for the inverse calculation of landuse-associated yields based on the sub-catchment outlets' yields derived from LI, GM, FW, and RC methods.

the unused fertilizer $\left(3000 \mathrm{~kg}-\mathrm{N} \mathrm{ha}^{-1} \mathrm{yr}^{-1}=300000 \mathrm{~kg}\right.$ $\mathrm{N} \mathrm{km}^{-2} \mathrm{yr}^{-1}$ ). Comparing with the reported values in the PLOAD, the $\mathrm{N}$ yield from the agriculture and woodland are $15.65 \mathrm{lbs} \mathrm{ac}^{-1} \mathrm{yr}^{-1}\left(=58375 \mathrm{~kg}-\mathrm{N} \mathrm{km}^{-2} \mathrm{yr}^{-1}\right)$ and $2.78 \mathrm{lbs} \mathrm{ac}^{-1} \mathrm{yr}^{-1}\left(=10369 \mathrm{~kg}-\mathrm{N} \mathrm{km}^{-2} \mathrm{yr}^{-1}\right)$ (EPA, USA, 
Table 4. The rating curves of $\mathrm{NO}_{3}-\mathrm{N}$ fluxes against water discharge.

\begin{tabular}{lll}
\hline Site & Power fitting, & $R^{2}$ \\
ID & $F=a Q^{b}:$ & \\
& {$\left[\mathrm{kg}-\mathrm{N} \mathrm{km}^{-2} \mathrm{day}^{-1}\right]$} \\
& $=\mathrm{a}\left[\mathrm{m}^{3} \mathrm{~s}^{-1}\right]^{b}$ & \\
\hline $\mathrm{Y} 7$ & $33.17 Q^{1.34}$ & 0.73 \\
$\mathrm{Y} 6$ & $32.60 Q^{1.22}$ & 0.89 \\
$\mathrm{Y} 5$ & $19.37 Q^{1.40}$ & 0.88 \\
$\mathrm{Y} 4$ & $30.74 Q^{1.28}$ & 0.84 \\
$\mathrm{Y} 3$ & $6.94 Q^{1.34}$ & 0.75 \\
$\mathrm{Y} 2$ & $22.04 Q^{0.91}$ & 0.59 \\
$\mathrm{Y} 1$ & $3.00 Q^{0.97}$ & 0.75 \\
$\mathrm{~T} 1$ & $1.13 Q^{1.14}$ & 0.66 \\
$\mathrm{C} 7$ & $0.35 Q^{1.04}$ & 0.68 \\
$\mathrm{C} 6$ & $0.74 Q^{1.43}$ & 0.79 \\
$\mathrm{C} 5$ & $468.33 Q^{0.84}$ & 0.81 \\
$\mathrm{C} 4$ & $1.35 Q^{1.21}$ & 0.86 \\
$\mathrm{~K} 1$ & $0.48 Q^{1.44}$ & 0.75 \\
$\mathrm{C} 3$ & $0.49 Q^{1.08}$ & 0.74 \\
$\mathrm{C} 2$ & $0.62 Q^{1.16}$ & 0.87 \\
$\mathrm{C} 1$ & $0.41 Q^{1.21}$ & 0.88 \\
\hline
\end{tabular}

2001). The over-fertilization in our study area is serious. However, this approach (i.e. PLOAD or our deconvolution method) which did not take the annual rainfall variation into account yet should be refined further. Nevertheless, our $\mathrm{NO}_{3}$ $\mathrm{N}$ yield factor may serve as a guideline for land management. It also indicates that preventing the fertilizer from being flushed away by typhoons is an efficient way to reduce farmers' cost and mitigate the nitrate flux.

\section{6 $\mathrm{NO}_{3}-\mathrm{N}$ budget in subtropics}

These observed $\mathrm{NO}_{3}-\mathrm{N}$ yield values (Table 5) are comparable with the background value in other watersheds in Taiwan (Kao et al., 2004). However, these background $\mathrm{N}$ yields in Taiwan are much higher than most of the pristine areas in the world (Lewis et al., 1999; Howarth et al., 1996). The high $\mathrm{N}$ yield can be attributed to high atmospheric deposition, which is partly from local emission and long-range transport from Mainland China (>4000 kg-N km ${ }^{-2} \mathrm{yr}^{-1}$; Bashkin and Park, 1998; Bouwman et al., 2002). Chen et al. (2004) concluded the $\mathrm{N}$ deposition at stations in Southern and South-eastern China is $\sim 2500-3800 \mathrm{~kg}_{-} \mathrm{N} \mathrm{km}^{-2} \mathrm{yr}^{-1}$, which agrees well with previously reported wet $\mathrm{N}$ deposition in Taiwan (1400 to $2300 \mathrm{~kg}-\mathrm{N} \mathrm{km}^{-2} \mathrm{yr}^{-1}$; King et al., 1994; Chen et al., 1998; Lin et al., 2000). If dry deposition is included, the $\mathrm{N}$ deposition will be even higher $(\sim 50 \%$ increase, Dr. S. C. Hsu, personal communication, 2011). The $\mathrm{N}$ deposition inputs to Taiwan are much larger compared to regions in unpolluted areas

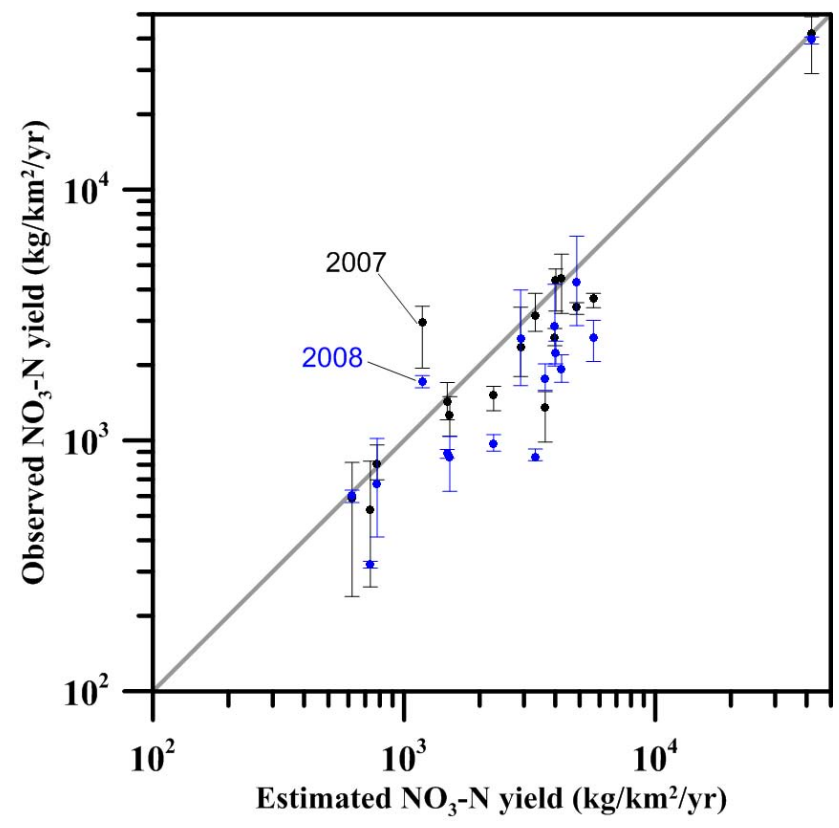

Fig. 7. The estimated (x-axis) and observed $\mathrm{NO}_{3}-\mathrm{N}$ yield (y-axis) for the 16 sites. The black and blue circles represent the results of 2007 and 2008, respectively. The error bars represent the ranges of four-method-derived yields for the observed yields. The diagonal line indicates the 1:1 line.

of Europe (Parker, 1983), North America, Japan (generally $<1500 \mathrm{~kg}-\mathrm{N} \mathrm{km}^{-2} \mathrm{yr}^{-1}$; Ohrui and Mitchell, 1997) and areas of similar latitudes (Prospero et al., 1996).

Except for the $\mathrm{N}$ deposition, another $\mathrm{N}$ input that should be highlighted is the geologic $\mathrm{N}$ input from the bedrock as reported by Holloway et al. (1998). The nitrogen contained in various bedrocks in Taiwan, reportedly, $0.1 \pm 0.02 \%$ (Hilton et al., 2010), is regarded as a high nitrogen content (Holloway and Smith, 2005). Their estimation on the nitrogen supply from the watershed bedrock lithologies was $~ 1000$ $2000 \mathrm{~kg}^{-\mathrm{N} \mathrm{km}}{ }^{-2} \mathrm{yr}^{-1}$ in the condition of $\sim 750 \mathrm{~mm}$ annual mean rainfall (one-third of annual rainfall amount in Taiwan). Besides, bedrock in Taiwan is so fragile that water can easily flow through the pores/cracks to further enhance deep weathering (Calmels et al., 2011), which might also stimulate bedrock-associated nitrogen output. Such environmental settings in Taiwan may exacerbate soil formation, which results in a potentially higher rate of $\mathrm{N}$ release from bedrock into soil. Overall, the high $\mathrm{N}$ supply to Taiwan watersheds from atmosphere and bedrock can facilitate a higher background $\mathrm{N}$ yield. Abundant nitrogen inputs, in addition to abundant rainfall, may reasonably explain the higher nitrate export in the study area.

Although the background $\mathrm{N}$ yield is high, it is still far lower than the $\mathrm{N}$ input from the atmosphere and bedrock. Thus, unreported biotic and/or abiotic processes such as forest uptake and biologically-mediated $\mathrm{N}$ removal should be 
Table 5. $\mathrm{NO}_{3}-\mathrm{N}$ flux derived from the 4 flux calculation methods for the 16 sites.

\begin{tabular}{|c|c|c|c|c|c|c|c|c|c|}
\hline \multirow{3}{*}{ Site ID } & \multicolumn{8}{|c|}{ Specific nitrate flux $\left(\mathrm{kg}-\mathrm{N} \mathrm{km}^{-2} \mathrm{yr}^{-1}\right)$} & \multirow{3}{*}{$\mathrm{SF}^{5}$} \\
\hline & \multicolumn{4}{|c|}{2007} & \multicolumn{4}{|c|}{2008} & \\
\hline & $\mathrm{LI}^{1}$ & $\mathrm{GM}^{2}$ & $\mathrm{FW}^{3}$ & $\mathrm{RC}^{4}$ & $\mathrm{LI}^{1}$ & $\mathrm{GM}^{2}$ & $\mathrm{FW}^{3}$ & $\mathrm{RC}^{4}$ & \\
\hline Y7 & 3147 & 2721 & 3855 & 2846 & 841 & 924 & 833 & 831 & $\mathrm{M}^{6}$ \\
\hline Y6 & 1306 & 1208 & 1465 & 1701 & 914 & 865 & 848 & 920 & $M^{6}$ \\
\hline Y5 & 1500 & 1312 & 1643 & 1633 & 1055 & 957 & 906 & 969 & $\mathrm{M}^{6}$ \\
\hline Y4 & 1160 & 1329 & 1494 & 1040 & 1030 & 1037 & 749 & 628 & $\mathbf{M}^{6}$ \\
\hline Y3 & 4145 & 4747 & 5531 & 3211 & 2195 & 2055 & 1704 & 1720 & $\mathrm{M}^{6}$ \\
\hline Y2 & 3426 & 3392 & 3065 & 1940 & 1726 & 1622 & 1706 & 1812 & $M^{6}$ \\
\hline Y1 & 4787 & 4823 & 4461 & 3278 & 2264 & 2159 & 2488 & 2021 & $\mathrm{~B}^{7}$ \\
\hline $\mathrm{T} 1$ & 586 & 817 & 705 & 238 & 602 & 565 & 603 & 633 & $\mathrm{M}^{6}$ \\
\hline $\mathrm{C} 7$ & 349 & 827 & 686 & 261 & 330 & 328 & 319 & 310 & $\mathrm{M}^{6}$ \\
\hline C6 & 2250 & 1798 & 1954 & 3394 & 2247 & 1653 & 2283 & 3982 & $\mathrm{M}^{6}$ \\
\hline C5 & 45275 & 48914 & 44919 & 28988 & 39946 & 38050 & 39908 & 40615 & $M^{6}$ \\
\hline $\mathrm{C} 4$ & 3546 & 3428 & 3400 & 3182 & 3837 & 2867 & 3901 & 6526 & $\mathrm{M}^{6}$ \\
\hline $\mathrm{K} 1$ & 782 & 696 & 771 & 961 & 610 & 413 & 638 & 1018 & $\mathrm{~B}^{7}$ \\
\hline $\mathrm{C} 3$ & 1420 & 1565 & 1439 & 985 & 1738 & 1584 & 1685 & 2018 & $\mathrm{M}^{6}$ \\
\hline $\mathrm{C} 2$ & 2794 & 2563 & 2569 & 2385 & 2588 & 1982 & 2610 & 4199 & $\mathrm{M}^{6}$ \\
\hline $\mathrm{C} 1$ & 3829 & 3381 & 3677 & 3854 & 2554 & 2064 & 2665 & 3012 & $\mathrm{~B}^{7}$ \\
\hline
\end{tabular}

${ }^{1} \mathrm{LI}=$ Linear interpolation, ${ }^{2} \mathrm{GM}=$ Global mean, ${ }^{3} \mathrm{FW}=$ Flow weighted, ${ }^{4} \mathrm{RC}=$ Rating curve method, ${ }^{5} \mathrm{SF}=$ Sampling frequency, ${ }^{6} \mathrm{M}=$ Monthly sampling, ${ }^{7} \mathrm{~B}=\mathrm{Biweekly}$ sampling

Table 6. The influences of monthly sampling and biweekly sampling schemes on estimating the observed $\mathrm{NO}_{3}-\mathrm{N}$ flux in the catchment outlets.

\begin{tabular}{|c|c|c|c|c|c|c|c|c|c|}
\hline \multirow{3}{*}{ Site ID } & \multicolumn{8}{|c|}{ Annual specific nitrate flux $\left(\mathrm{kg}-\mathrm{N} \mathrm{km}{ }^{-2} \mathrm{yr}^{-1}\right)$} & \multirow{3}{*}{$\mathrm{SF}^{5}$} \\
\hline & \multicolumn{4}{|c|}{2007} & \multicolumn{4}{|c|}{2008} & \\
\hline & $\mathrm{LI}^{1}$ & $\mathrm{GM}^{2}$ & $\mathrm{FW}^{3}$ & $\mathrm{RC}^{4}$ & $\mathrm{LI}^{1}$ & $\mathrm{GM}^{2}$ & $\mathrm{FW}^{3}$ & $\mathrm{RC}^{4}$ & \\
\hline Y1 & 4787 & 4823 & 4461 & 3278 & 2264 & 2159 & 2488 & 2021 & $\mathrm{~B}^{7}$ \\
\hline $\mathrm{K} 1$ & 782 & 696 & 771 & 961 & 610 & 413 & 638 & 1018 & $B^{7}$ \\
\hline $\mathrm{C} 1$ & 3829 & 3381 & 3677 & 3854 & 2554 & 2064 & 2665 & 3012 & $\mathrm{~B}^{7}$ \\
\hline Y1 & 4812 & 5271 & 6155 & 4068 & 2226 & 2219 & 2005 & 1907 & $M^{6}$ \\
\hline $\mathrm{K} 1$ & 584 & 533 & 583 & 1242 & 476 & 432 & 470 & 512 & $M^{6}$ \\
\hline $\mathrm{C} 1$ & 4118 & 3562 & 4019 & 5675 & 2543 & 2147 & 2513 & 3233 & $\mathrm{M}^{6}$ \\
\hline
\end{tabular}

${ }^{1} \mathrm{LI}=$ Linear interpolation, ${ }^{2} \mathrm{GM}=$ Global mean, ${ }^{3} \mathrm{FW}=$ Flow weighted, ${ }^{4} \mathrm{RC}=$ Rating curve method, ${ }^{5} \mathrm{SF}=\mathrm{Sampling}$ frequency, ${ }^{6} \mathrm{M}=\mathrm{Monthly}$ sampling, ${ }^{7} \mathrm{~B}=\mathrm{Biweekly}$ sampling

addressed. The isotopic compositions of $\mathrm{N}$ and $\mathrm{O}$ in $\mathrm{NO}_{3}$ have been measured for most of the network stations in our study watersheds. For almost all stations, no significant ${ }^{15} \mathrm{~N}$ in $\mathrm{NO}_{3}$ was observed, indicating that $\mathrm{N}$ removal via denitrification plays a minor role in our streams (Peng et al., 2007, 2012). Possibly, the quick recharging does not allow the denitrification signal to accumulate, unlike the large long residence-time continental rivers (David et al., 1997; Royer et al., 2004). Another possibility is the vegetation uptake. Contrary to a well known fact that the uptake and storage of a mature forest is limited, forests in Taiwan are most young. High sediment production due to the typhoonand earthquake-induced landsliding is one of the major mass wasting which results in forest elimination (Lin et al., 2003; West et al., 2011). Bedrock exposure accelerates a fast turnover rate for forest re-growth and soil formation in terms of $\mathrm{N}$ storage. The uptake by growing forest might be responsible for the offset between input and output. There are some 
Table 7. The annual $\mathrm{NO}_{3}-\mathrm{N}$ flux observed in this study and those around the world.

\begin{tabular}{lrrlll}
\hline Region & $\begin{array}{r}\text { Site } \\
\text { number }\end{array}$ & $\begin{array}{r}\text { Runoff } \\
\left(\mathrm{mm} \mathrm{yr}^{-1}\right)\end{array}$ & $\begin{array}{l}\text { Anthropogenic } \\
\text { land (\%) }\end{array}$ & $\begin{array}{l}\mathrm{NO}_{3}-\mathrm{N} \text { yield } \\
\left(\mathrm{kg}-\mathrm{N} \mathrm{km}^{-2} \mathrm{yr}^{-1}\right)\end{array}$ & Citation \\
\hline Northeastern US & 8 & 591 & 9.81 & 132.9 & Mayer et al. (2002) \\
Northeastern US & 8 & 500 & 32.85 & 582.8 & Mayer et al. (2002) \\
Illinois, US & 1 & $\sim 400$ & 91 & $\sim 4000$ & David et al. (1997) \\
California, USA & 11 & 421 & 3.2 & 58.0 & Sobota et al. (2009) \\
California, USA & 12 & 235 & 24.4 & 170.9 & Sobota et al. (2009) \\
Central Germany & 3 & 117 & 66.2 & $1850-4120$ & Rode et al. (2009) \\
Germany & 2 & $257-538$ & $<1.0$ & $336-493$ & Langusch et al. (2002) \\
Northeastern Australia & 13 & 965 & 0.4 & 284 & Hunter et al. (2008) \\
Northeastern Australia & 3 & 1960 & 1.0 & 2304 & Hunter et al. (2008) \\
Northern Taiwan & 4 & 2100 & $<0.1$ & 660 & Kao et al. (2004) \\
Northern Taiwan & 4 & 2100 & 5 & 2550 & Kao et al. (2004) \\
Central Taiwan & 3 & 3300 & $<0.1$ & 585 & This study \\
Central Taiwan & 12 & 3300 & $0.6-8.9$ & $1058-3836$ & This study \\
Central Taiwan & 1 & 3300 & 24.7 & 40827 & This study \\
\hline
\end{tabular}

${ }^{1}$ Our values reported here were the average of the 8 values (4-methods-derived estimation in two years). ${ }^{2}$ Meant the C5 site derived from Table 5.

Table 8. The annual $\mathrm{NO}_{3}-\mathrm{N}$ yield for each land use class.

\begin{tabular}{lrrrr}
\hline & \multicolumn{3}{c}{$\mathrm{NO}_{3}-\mathrm{N}$ annual yield $\left(\mathrm{kg}-\mathrm{N} \mathrm{km}^{-2} \mathrm{yr}^{-1}\right)$} \\
\cline { 2 - 5 } Land use class & Average & $\begin{array}{c}\text { Standard } \\
\text { deviation }\end{array}$ & Maximum & Minimum \\
\hline Natural forest & 351 & 62 & 676 & 300 \\
Mixed forest & 629 & 109 & 1015 & 506 \\
Secondary forest & 1064 & 73 & 1316 & 1000 \\
Grass & 2806 & 273 & 3918 & 2500 \\
Bare land & 2008 & 216 & 2494 & 1703 \\
Orchard & 5456 & 290 & 5981 & 5005 \\
Active farm & 308170 & 19241 & 349749 & 270120 \\
Inactive farm & 77147 & 2256 & 84910 & 75003 \\
\hline
\end{tabular}

important processes to mediate $\mathrm{N}$ removal. More research is needed to resolve these issues for understanding the nitrogen cycling in subtropics.

\section{Conclusions}

Land use, particularly agricultural land, is regarded as a significant factor dominating nitrate export. Understanding the contribution of each land use to nitrate export is fundamental for assessing the impacts of land use change on water quality. However, different environmental settings and agricultural activities might result in varied nitrate export; hence, local land use planning and management should be based on regional information. In this study, we investigated 16 nested catchments within the Chi-ChiaWan watershed and attempted to characterize each individual land-use-associated nitrate yield through observational networks and deconvolution computations. This study provided rarely documented information in the subtropical mountainous area and could be used as a comparison to other climatic areas around the world.

We found that the nitrate concentration in pristine catchments is approximately $0.145 \mathrm{mg} \mathrm{l}^{-1}$, which is comparable with other forestry catchments worldwide. However, the annual $\mathrm{NO}_{3}-\mathrm{N}$ export was much higher at 238-1018 kg$\mathrm{N} \mathrm{km}^{-2} \mathrm{yr}^{-1}$ due to higher rainfall, $\mathrm{N}$ deposition, and soil mineralized $\mathrm{N}$. We also found that a small fraction $(\sim 0.6 \%$ in Y6 station) of a catchment subject to agricultural activities could result in approximately 2 times of $\mathrm{NO}_{3}-\mathrm{N}$ export $\left(\sim 848-1701 \mathrm{~kg}^{-} \mathrm{N} \mathrm{km}^{-2} \mathrm{yr}^{-1}\right)$ than in the pristine areas. This result reveals that the nitrate yield in subtropical mountainous regions is highly sensitive to small agricultural disturbances.

Based on these intensive observations, $\mathrm{NO}_{3}-\mathrm{N}$ yields for each land use class were estimated. The active vegetable farm yielded $308170 \pm 19241 \mathrm{~kg}-\mathrm{N} \mathrm{km}^{-2} \mathrm{yr}^{-1}$ which was 3 orders of magnitude higher than that of forestry. Even the inactive vegetable farm, where farmers stopped fertilizing, yielded $77147 \pm 2256 \mathrm{~kg} \mathrm{~N} \mathrm{~km}^{-2} \mathrm{yr}^{-1}$, which implies the lingering influence of agricultural activities on stream nitrate concentration. The estimated nitrate yield for each land use class offers a useful basis for land management to assess the impacts of land use changes.

After analyzing the nitrogen budget within the watersheds, the atmospheric deposition and soil mineralized inputs (not including biological nitrogen fixation) are much larger than the background nitrate yield of $585 \mathrm{~kg}-\mathrm{N} \mathrm{km}^{-2} \mathrm{yr}^{-1}$. This implies that there are certain unreported biotic and/or abiotic processes, such as forest uptake and biologically-mediated $\mathrm{N}$ 
removal, that should be addressed. More research is needed to resolve these issues for understanding the nitrogen cycling in subtropics.

Acknowledgements. This study is funded by Taiwan NSC projects, NSC 100-2116-M-002-016, and the National Taiwan University project, NTU 10R70604-2. We also thank the Taiwan Power Company, the Shei-Pa National Park Ministration, and the Water Resources Agency for providing weather and hydrological records.

Edited by: N. Romano

\section{References}

Bashkin, V. and Park, S. U.: Acid Deposition and Ecosystem Sensitivity in East Asia, Nova Science Publishers, Hauppauge, NY, 423 pp., 1998.

Birgand, F., Faucheux, C., Gruau, G., Augeard, B., Moatar, F., and Bordenave, P.: Uncertainties in assessing annual nitrate load and concentration indicators, 1. Impact of sampling frequency and load estimation algorithms, Trans. ASABE, 53, 1-10, 2010.

Boesch, D. F., Brinsfield, R. B., and Magnien, R. E.: Chesapeake Bay eutrophication: Scientific understanding, ecosystem restoration, and challenges for agriculture, J. Environ. Qual., 30, 303$320,2001$.

Bouwman, A. F., Boumans, L. J. M., and Batjes, N. H.: Estimation of global NH3 volatilization loss from synthetic fertilizers and animal manure applied to arable land and grasslands, Global Biogeochem. Cy., 16, 1024, doi:10.1029/2000GB001389, 2002.

Burns, D. A., Murdoch, P. S., Lawrence, G. B., and Michel, R. L.: Effects of groundwater springs on $\mathrm{NO}_{3}-\mathrm{N}$ concentrations during summer in Catskill Mountain stream, Water Resour. Res., 34, 1987-1996, doi:10.1029/98WR01282, 1998.

Calmels, D., Galy, A., Hovius, N., Bickle, M., West, A. J., Chen, M. C., and Chapman, H.: Contribution of deep groundwater to the weathering budget in a rapidly eroding mountain belt, Taiwan, Earth Planet. Sc. Lett., 303, 48-58, 2011.

Chen, X. Y., Mulder, J., Wang, Y. H., Zhao, D. W., and Xiang, R. J.: Atmospheric deposition, mineralization and leaching of nitrogen in subtropical forested catchments, South China, Environ. Geochem. Health, 26, 179-186, 2004.

Chen, Z. S., Liu, J. C., and Cheng, C. Y.: Acid deposition effects on the dynamic of heavy metals in soils and their biological accumulation in the crops and vegetables in Taiwan, in: Acid Deposition and Ecosystem Sensitivity in East Asia, edited by: Bashkin, V. and Park, S. U., Nova Science Publishers, Hauppauge, NY, 188225, 1998

Creed, I. F. and Band, L. E.: Exploring functional similarity in the export of nitrate-N from forest catchments: a mechanistic modeling approach, Water Resour. Res., 34, 3079-3093, 1998.

Crimo, C. P. and McDonnell, J. J.: Linking the hydrological and biogeochemical controls of nitrogen transport in near-stream zones of temperate-forested catchments: a review, J. Hydrol., 199, 88-120, 1997.

D'Arcy, P. and Carignan, R.: Influence of catchment topography on water chemistry in southeastern Quebec Shield lakes, Can. J. Fish. Aquat. Sci., 54, 2215-2227, 1997.
David, M. B. and Gentry, L. E.: Anthropogenic Inputs of Nitrogen and Phosphorus and Riverine Export for Illinois, USA, J. Environ. Qual., 29, 494-508, 2000.

David, M. B., Gentry, L. E., Kovacic, D. A., and Smith, K. M.: Nitrogen Balance in and Export from an Agricultural Watershed, J. Environ. Qual., 26, 1038-1048, 1997.

De Smedt, F., Liu, Y. B., and Gebremeskel, S.: Hydrological modeling on a catchment scale using GIS and remote sensed land use information, in: Risk Analysis II, edited by: Brebbia, C. A., WTI Press, Southampton, Boston, 295-304, 2000.

De Vries, W., Kros, J., Oenema, O., and De Klein, J.: Uncertainties in the fate of nitrogen II: A quantitative assessment of the uncertainties in major nitrogen fluxes in the Netherlands, Nutr. Cycl. Agroecosyst., 66, 71-102, 2003.

Dumont, E., Harrison, J. A., Kroeze, C., Bakker, E. J., and Seitzinger, S. P.: Global distribution and sources of dissolved inorganic nitrogen export to the coastal zone: Results from a spatially explicit, global model, Global Biogeochem. Cy., 19, GB4S02, doi:10.1029/2005GB002488, 2005.

EPA, USA: User's Manual of PLOAD version 3.0: An Arcview GIS Tool to Calculate Nonpoint Sources of Pollution in Watershed and Storwater Projects, 2001.

Galloway, J. N., Levy, H., and Kasibhatia, P. S.: Year 2020: Consequences of population growth and development on deposition of oxidized nitrogen, Ambio, 23: 120-123, 1994.

Galloway, J. N., Aber, J. D., Erisman, J. W., Seitzinger, S. P., Howarth, R. W., Cowling, E. B., and Cosby, B. J.: The nitrogen cascade, Bioscience, 53, 341-356, 2003.

Günter, A., Uhlenbrook, S., Seibert, J., and Keibundgut, C.: Multicriterial validation of TOPMODEL in a mountainous catchment, Hydrol. Process., 13, 1603-1620, 1999.

Herlihy, A. T., Stoddard, J. L., and Johnson, C. B.: The relationship between stream chemistry and watershed land cover data in the Mid-Atlantic region, U.S., Water Air Soil Poll., 105, 377-386, 1998.

Hilton, R. G., Galy, A., and Hovius, N.: Riverine particulate organic carbon from an active mountain belt: Importance of landslides, Global Biogeochem. Cy., 22, GB1017, doi:10.1029/2006GB002905, 2008.

Hilton, R. G., Galy, A., Hovius, N., Horng, M. J., and Chen, H.: The isotopic composition of particulate organic carbon in mountain rivers of Taiwan, Geochim. Cosmochim. Acta, 74, 3164-3181, 2010.

Holloway, J. M. and Smith, R. L.: Nitrogen and carbon flow from rock to water: Regulation through soil biogeochemical processes, Mokelumne River watershed, California, and Grand Valley, Colorado, J. Geophys. Res., 110, F01010, doi:10.1029/2004JF000124, 2005.

Holloway, J. M., Dahlgren, R. A., Hansen, B., and Casey, W. H.: Contribution of bedrock nitrogen to high nitrate concentrations in stream water, Nature, 395, 785-788, 1998.

Hooke, R. L.: Spatial distribution of human geomorphic activity in the United States: Comparison with rivers, Earth Surf. Proc. Land., 24, 687-692, 1999.

Howarth, R. W., Billen, G., Swaney, D., Townsend, A., Jaworski, N., Lajtha, K., Downing, J. A., Elmgren, R., Caraco, N., Jordan, T., Berendse, F., Freney, J., Kuderyarov, V., Murdoch, P., and Zhaoliang, Z.: Regional nitrogen budgets and riverine $\mathrm{N}$ and $\mathrm{P}$ fluxes for the drainages of the North Atlantic Ocean: Natural and 
human influences, Biogeochemistry, 35, 75-140, 1996.

Howarth, R. W., Sharpley, A., and Walker, D.: Sources of nutrient pollution to coastal waters in the United States: Implications for achieving coastal water quality goals, Estuaries, 25, 656-676, 2002.

Huang, J.-C., Lee, T.-Y., and Kao, S.-J.: Simulating typhooninduced storm hydrographs in subtropical mountainous watershed: an integrated 3-layer TOPMODEL, Hydrol. Earth Syst. Sci., 13, 27-40, doi:10.5194/hess-13-27-2009, 2009.

Huang, J. C., Kao, S. J., Lin, C. Y., and Li, M. H.: Effect of subsampling tropical cyclone rainfall on flood hydrograph responses in subtropical mountainous catchment, J. Hydrol., 409, 248-261, doi:10.1016/j.jhydrol.2011.08.037, 2011a.

Huang, J. C., Lin, C. C., Chan, S. C., Lee, T. Y., Hsu, S. C., Lee, C. T., and Lin, J. C.: Stream discharge characteristics through urbanization gradient in Danshui River, Taiwan: perspectives from observation and simulation, Environ. Monitor. Assess, doi:10.1007/s10661-011-2374-2, in press, 2011b.

Hunter, H. M. and Walton, R. S.: Land-use effects on fluxes of suspended sediment, nitrogen and phosphorus from a river catchment of the Great Barrier Reef, Australia, J. Hydrol., 356, 131146, 2008 .

Johnson, C. E., Driscoll, C. T., Siccama, T. G., and Likens, G. E.: Element fluxes and landscape position in a northern hardwood forest watershed ecosystem, Ecosystems, 3, 159-184, 2000.

Kalita, P. K., Cooke, R. A. C., Anderson, S. M., Hirschi, M. C., and Mitchell, J. K.: Subsurface drainage and water quality: The Illinois experience, Trans. ASABE, 50, 1651-1656, 2007.

Kao, S. J. and Liu, K. K.: Stable carbon and nitrogen isotope systematics in a human-disturbed watershed (Lanyang-Hsi) in Taiwan and the export of biogenic particulate matter, Global Biogeochem. Cy., 14, 189-198, 2000.

Kao, S. J. and Milliman, J. D.: Water and sediment discharge from small mountainous rivers, Taiwan: The roles of lithology, episodic events, and human activities, J. Geol., 116, 431-448, 2008.

Kao, S. J., Shiah, F. K., and Owen, J. S.: Export of dissolved inorganic nitrogen in a partially cultivated subtropical mountainous watershed in Taiwan, Water Air Soil Poll., 156, 211-228, 2004.

Kao, S. J., Lee, T. Y., and Milliman, J. D.: Calculating highly fluctuated suspended sediment fluxes from mountainous rivers in Taiwan, Terr. Atmos. Ocean. Sci., 16, 653-675, 2005.

King, H. B., Hsia, Y. J., Liou, C. B., Lin, T. C., Wang, L. J., and Hwong, J. L.: Chemistry of precipitation, throughfall, stem flow and streamwater of six forest sites in Taiwan, in: Biodiversity and Terrestrial Ecosystem, edited by: Peng, C. I. and Chou, C. H., Institute of Botany, Academia Sinica, Taiwan, 355-362, 1994.

Lane, S. N., Brookes, C. J., Heathwaite, A. L., and Reaney, S.: Surveillant Science: Challenges for the management of rural environments emerging from the new generation diffuse pollution models, J. Agr. Econom., 57, 239-257, 2006.

Langusch, J.-J. and Matzner, E.: N fluxes in two nitrogen saturated forested catchments in Germany: dynamics and modelling with INCA, Hydrol. Earth Syst. Sci., 6, 383-394, doi:10.5194/hess-6383-2002, 2002.

Lee, T. Y., Carey, A. E., Huang, J. C., and Kao, S. J.: Sampling strategy and optimal estimator to obtain reliable material fluxes from high-standing rivers in Taiwan, Asia Oceania Geosciences Society, 4th Annual Meeting, July-August, Bangkok, Thailand,
2007.

Legates, D. R.: Global and terrestrial precipitation: A comparative assessment of existing climatologies, Int. J. Climatol., 15, 237 258, 1995.

Lewis, W. M., Melack Jr., J. M., McDowell, W. H., McClain, M., and Richey, J. E.: Nitrogen yields from undisturbed watersheds in the Americas, Biogeochemistry, 46, 149-162, 1999.

Lin, K. C., Duh, C. T., Ma, F. C., and Wang, H. H.: Biomass and nutrient content of woody debris in the Fu-shan subtropical broadleaf forest of northeastern Taiwan, Taiwan J. Forest. Sci., 18, 235-244, 2003.

Lin, T. C., Hamburg, S. P., King, H. B., and Hsia, Y. J.: Throughfall patterns in a subtropical rain forest of northeastern Taiwan, J. Environ. Qual., 29, 1186-1193, 2000.

Mayer, B., Boyer, E. W., Goodale, C., Jaworski, N. A., Van Breemen, N., Howarth, R. W., Seitzinger, S., Billen, G., Lajtha, L. J., Nosal, M., and Paustian, K.: Sources of nitrate in rivers draining sixteen watersheds in the northeastern US: Isotopic constraints, Biogeochemistry, 57, 171-197, 2002.

Meador, M. R. and Goldstein, R. M.: Assessing water quality at large geographic scales: Relations among landuse, water physicochemistry, riparian condition, and fish community structure, Environ. Manage., 31, 504-517, 2003.

Moatar, F. and Meybeck, M.: Compared performances of different algorithms for estimating annual nutrient loads discharged by the eutrophic river Loire, Hydrol. Process., 19, 429-444, 2005.

Munaf, M., Cecchi, G., Baiocco, F., and Mancini, L.: River pollution from non-point sources: a new simplified method of assessment, J. Environ. Manage., 77, 93-98, 2005.

Nash, J. E. and Sutcliffe, V. : River flow forecasting through conceptual models part I - A discussion of principles, J. Hydrol., 10, 282-290, 1970.

Ogawa, A., Shibata, H., Suzuki, K., Mitchell, M. J., and Ikegami, Y.: Relationship of topography to surface water chemistry with particular focus on nitrogen and organic carbon solutes within a forested watershed in Hokkaido, Japan, Hydrol. Process., 20, 251-265, 2006.

Ohrui, K. and Mitchell, M. J.: Nitrogen saturation in Japanese forested watersheds, Ecol. Appl., 7, 391-401, 1997.

Ohrui, K. and Mitchell, M. J.: Spatial patterns of soil nitrate in Japanese forested watersheds: importance of the near-stream zone as a source of nitrate in streamwater, Hydrol. Process., 12, 1433-1445, 1998.

Parker, G. G.: Throughfall and streamflow in the forest nutrient cycle, Adv. Ecol. Res., 13, 57-133, 1983.

Peng, T. R., Fan, C. H., Lin, H. J., and Tung, C. C.: Sources of river nitrate in Wu-Ling area, J. Chin. Soil Water Conserv., 38, 385-398, 2007.

Peng, T. R., Lin, H. J., Wang, C. H., Liu, T. S., and Kao, S. J.: Pollution and variation of stream nitrate in a protected highmountain watershed of central Taiwan: Evidence from nitrate concentration, and nitrogen and oxygen isotope compositions, Environ. Monitor. Assess., doi:10.1007/s10661-011-2314-1, in press, 2012.

Poor, C. J. and McDonnell, J. J.: The effects of land use on stream nitrate dynamics, J. Hydrol., 332, 54-68, 2007.

Prospero, J. M., Barrett, K., Church, T., Dentener, F., Duce, R. A., Galloway, J. N., Levy, H., Moody, J., and Quinn, P.: Atmospheric deposition of nutrients to the North Atlantic Basin, 
Biogeochemistry, 35, 27-73, 1996.

Rabalais, N. N.: Nitrogen in aquatic ecosystems, Ambio, 31, 102112,2002

Rode, M., Thiel, E., Franko, U., Wenk, G., and Hesser, F.: Impact of selected agricultural management options on the reduction of nitrogen loads in three representative meso scale catchments in Central Germany, Sci. Total Environ., 407, 3459-3472, 2009.

Rose, S. and Peters, N. E.: Effects of urbanization on streamflow in the Atlantic area (Georgia, USA): A comparative hydrological approach, Hydrol. Process., 15, 1441-1457, 2001.

Royer, T. V., Tank, J. L., and David, M. B.: Transport and Fate of Nitrate in Headwater Agricultural Streams in Illinois, J. Environ. Qual., 33, 1296-1304, 2004.

Sobota, D. J., Harrison, J. A., and Dahlgren, R. A.: Influence of climate, hydrology, and land use on input and export of nitrogen in California watersheds, Biogeochemistry, 94, 43-62, doi:10.1007/s10533-009-9307-y, 2009.

Swank, W. T., Vose, J. M., and Elliott, K. J.: Long-term hydrological and water quality responses following commercial clearcutting of mixed hardwoods on a southern Appalachian catchment, Forest Ecol. Manage., 143, 163-178, 2001.

Tanaka, M. and Suzuki, K.: Influence of Watershed Topography on the Chemistry of Stream Water in a Mountainous Area, Water Air Soil Poll., 196, 321-331, 2009.
Vitousek, P. M., Mooney, H. A., Lubchenco, J., and Melillo, J. M.: Human Domination of Earth's Ecosystems, Science, 277, 494499, 1997.

Walton, R. S. and Hunter, H. M.: Isolating the water quality responses of multiple land uses from stream monitoring data through model calibration, J. Hydrol., 378, 29-45, 2009.

Welch, K. A., Lyons, W. B., Graham, E., Neumann, K., Thomas, J. M., and Mikesell, D.: Determination of major element chemistry in terrestrial waters from Antarctica by ion chromatography, J. Chromatogr. A, 739, 257-263, 1996.

Wellington, B. I. and Driscoll, C. T.: The episodic acidification of a stream with elevated concentrations of dissolved organic carbon, Hydrol. Process., 18, 2663-2680, 2004.

West, A. J., Lin, C. W., Lin, T. C., Hilton, R. G., Liu, S. H., Chang, C. T., Lin, K. C., Galy, A., Sparkes, R. B., and Hovius, N.: Mobilization and transport of coarse woody debris to the oceans triggered by an extreme tropical storm, Limnol. Oceanogr., 56, 77-85, doi:10.4319/lo.2011.56.1.0077, 2011.

Zhang, Q. F., Xu, Z. F., Shen, Z. H., Li, S. Y., and Wang, S. S.: The Han River watershed management initiative for the South-toNorth Water Transfer project (Middle Route) of China, Environ. Monitor. Assess., 148, 369-377, 2009. 